\title{
From the cage to the wild: Introductions of Psittaciformes to Puerto Rico with emphasis on the invasive ecology of the white-winged parakeet
}

\author{
Wilfredo Falcón L. ${ }^{1,2, *}, \dagger$ and Raymond L. Tremblay ${ }^{1,2}$ \\ ${ }^{1}$ Department of Biology, University of Puerto Rico at Humacao, \\ 100 Carr. 908, Humacao, Puerto Rico 00791, USA. \\ 2 Center for Applied Tropical Ecology and Conservation, PO BOX 23341, University of \\ Puerto Rico, Río Piedras, Puerto Rico, 00931-3341. \\ * Corresponding author: wilfredo.falcon@ieu.uzh.ch
}

$\dagger$ Present address: Department of Evolutionary Biology and Environmental Studies, University of Zürich, Winterthurerstrasse 190, 8057 Zürich, Switzerland. 


\begin{abstract}
In this study, we assessed invasions of Psittaciformes in Puerto Rico. We reviewed the literature, public databases, citizen science records, and performed in situ population surveys across the island to determine the historical and current status and distribution of psittacine species. We used count data from Ebird to determine population trends. For species whose populations were increasing, we modelled their potential distribution using niche modeling techniques. Focusing on the white-winged parakeet (Brotogeris versicolurus), which was considered the most successful psittacine species by the year 2000, we evaluated the population size, calculated growth rates and estimated the breeding proportion in two populations by performing roost counts for four consecutive years. We found a total of 46 Psittaciformes present in Puerto Rico, of which $26 \%$ are only present as pets, at least 29 species have been reported in the wild, and of those, there is evidence that at least 12 species are breeding. Our results indicate that most introduced species which have been detected as established still persist, although mostly in localized areas and small populations. Clear evidence of invasiveness was found for $B$. versicolurus and Myiopsitta monachus, which have greatly expanded their range. Moreover, Psittacara erythrogenys and Eupsittacula canicularis also showed population increase. The niche models predicted suitable areas for the four species, and also indicate the potential for range expansion. Population estimates of the white-winged parakeet during the study period showed a steady increase, and exhibited exponential growth, with geometric mean population growth rates of 1.25 per year. Currently growth rate of the white-winged parakeet does not appear to be limited by any predator, resources or nest availability, and we expect them to continue increasing and expanding their range. We discuss the factors leading to invasion success, assess the potential impacts, and we discuss possible management strategies and research prospects.
\end{abstract}

Key words: biological invasions; birds; Cacatuidae; islands; parrots, population growth; Psittacidae; Puerto Rico 


\section{Introduction}

Over the last decades, the rate of species introductions has risen considerably, mirroring the rise of international trade, and the shifts in species distributions and the reorganization of biodiversity are now considered a signature of the Anthropocene (Seebens et al., 2017). In parallel, the study of invasive species has gained broad attention from ecologists, government agencies and the public due to the potential negative economical, ecological and environmental impact that these may cause on ecological processes and patterns (Sanders et al., 2003; Mooney, 2005; Davis, 2009; Lockwood, Hoopes \& Marchetti, 2013). One of the factors that most contributed to the establishment of nonnative species in recent history has been the pet trade (Smith et al., 2009).

Among the species commonly sold as exotics are Psittaciformes (parrots, conures and cockatoos; hereon referred to collectively as parrots), with around two-thirds of species being transported outside their native range (Cassey et al., 2004b). It has been estimated that around USD \$1.4 billion were generated during the 1990's as a result of the global trade with Psittaciformes, and that around four million birds were captured from the wild to supply the demand of the pet trade industry (Thomsen et al., 1992). Four general modes of introductions have been identified for parrots: releases by traders due to oversupply or legal complications (Forshaw, 1973; Robinson, 2001), or the accidental or intentional releases by pet owners (Blackburn, Lockwood \& Cassey, 2009).

Two thirds of successful avian introductions have been on islands (Blackburn, Lockwood \& Cassey, 2009). Many species of Psittaciformes have been imported to be sold as pets in Puerto Rico, especially since the 1950's and as many as eight species of parrots have been recorded as established (or probably established) by early 2000 (Pérez- 
Rivera, 1985; Raffaele, 1989; Camacho-Rodríguez, Chabert-Llompart \& López-Flores, 1999; Oberle, 2000). In Puerto Rico, there is evidence that three endemic species of parrots have been present on the island, but the only extant species is the endemic Puerto Rican amazon (Amazona vittata vitta) and the two others species, Amazona v. gracipiles and Psittacara maugei having gone extinct (Snyder, Wieley \& Kepler, 2007; Olson, 2015). As with any exotic and invasive species, local federal and state agencies are concerned with the possible effects that these species may have on indigenous species and the ecosystem, and managing agencies want to have information about the size, distribution and spread of exotic populations.

For example, the white-winged parakeet (Brotogeris versicolurus) has been considered the most successful psittacine species established in Puerto Rico (PérezRivera et al., 1985; Raffaele, 1989; Camacho-Rodríguez, Chabert-Llompart \& LópezFlores, 1999; Oberle, 2000). Although Pérez-Rivera et al. (1985) alerted that the whitewinged parakeet could expand and cause significant damage to crops, there is no evidence that this has yet materialized. Previous surveys has confirmed the persistence of locally common and self-sustaining populations of the white winged parakeet (PérezRivera et al., 1985; Raffaele, 1989; Camacho-Rodríguez, Chabert-Llompart \& LópezFlores, 1999; Oberle, 2000). Since 2004, and 35 years after it was first reported in the wild in Puerto Rico, the population in the Metropolitan Area of San Juan appeared to be expanding aggressively. This brought renewed concerns about the possible negative effects that the parakeet might have on the native flora and fauna if the white-winged parakeet kept expanding its range, and on the agricultural sector.

In this study, we present a review on the introduction and persistence of 
Psittaciformes in Puerto Rico, and evaluated their historic and present distribution. In more detail, we assess the invasive ecology of the white-winged parakeet - including aspects of their natural history, population estimates, and population growth rates. Also, we present the predicted distribution of white-winged parakeets on the island based on niche modelling techniques. Finally, we address possible factors that may have contributed to the establishment success of species of Psittaciformes in Puerto Rico, and discuss our results in the context of management and prospects.

\section{Materials and Methods}

\section{Introductions of Psittaciformes to Puerto Rico}

Members of the Psittaciformes, which comprise about 393 species in 92 genera that include macaws, cockatoos, parrots, and conures, are mostly pantropical, although some species inhabit temperate areas in the southern hemisphere (Juniper \& Parr, 1998; Forshaw, 2010). They are considered one of the most endangered groups of birds in the world, and threats include trapping for trade, habitat destruction and hunting (Snyder et al., 2000).

Historical and current status of Psittaciformes.- To assess the historical introductions of Psittaciformes to Puerto Rico, and their current status, we surveyed historical reports on the distribution of the species (Forshaw, 1973; Pérez-Rivera \& Vélez-Miranda, 1980; Pérez-Rivera, 1985; Pérez-Rivera et al., 1985; Raffaele, 1989; Camacho-Rodríguez, Chabert-Llompart \& López-Flores, 1999; Oberle, 2000) . We also recorded species based on observations performed during 2013-2017. In addition, we surveyed the E-bird (http://ebird.com/) online database, which contain records from 
citizen-science-derived reports and from experts. Moreover, performed searches on online local birding groups for photographic records using the search terms 'parrot', 'parakeet', 'macaw', 'cockatoo' in English and Spanish. The local groups included: Aves de Puerto Rico (https://www.facebook.com/avesdepuertoricoFelPe/), the Puerto Rico Ornithological Society (https://www.facebook.com/sociedadornitologicapuertorriquena/), Bird Photographers of Puerto Rico (https://www.facebook.com/groups/615958701756859/), and Biodiversidad de Puerto Rico (https://www.facebook.com/groups/PRNatural/). This was done between November-December 2017 (see electronic supplementary information S1 for the origin of the data). To identify species sold as pets but not seen in the wild, we visited pet stores, mainly in the Metropolitan Area of San Juan, and the pets section of local online classified ads Clasificados Online (www.clasificadosonline.com). Moreover, the online databases Ebird, CABI Invasive Species Compendium (https://www.cabi.org/isc) and the Global Invasive Species Database (http://www.iucngisd.org/gisd) were used to assess the invasiveness of species of Psittaciformes have reached in their non-native range (outside Puerto Rico) in the categorization scheme of invasive species according to (Blackburn et al., 2011; see Table 1). We also used the latter scheme to classify the status (invasiveness) of Psittaciformes in Puerto Rico. We used Forshaw (2010) for taxonomical classification and common names of Psittaciformes, the native distribution, and include any classification changes according to del Hoyo et al. (2014). The IUCN Red List (ver. 3.1; www.iucnredlist.org) was used to assess the conservation status for each species, population trends in their native range, and possible threats or reasons for population increase. 
Sighting trends of Psittaciformes in Puerto Rico.- To assess the sighting trends of Psittaciformes in Puerto Rico, we used observation count reports from Ebird for each species (see electronic supplementary information S2 for count data). We calculated the mean number of birds counted per municipality/year (where they have been observed), and then summed the mean number of birds per municipality to obtain the island-wide counts per year. Only species with at least 20 records were included in the subsequent analysis in this paper.

Distribution of Psittaciformes in Puerto Rico.- We assess the current distribution of the different psittacine species found in Puerto Rico by surveying Ebird for georeferenced records (see electronic supplementary information S2 for location records). After identifying psittacine species whose sighting trends showed an increase, we employed niche-modeling techniques following the methodology used by Falcón, Ackerman \& Daehler (2012) \& Falcón et al. (2013). To construct the distribution models, we used the Maximum Entropy Method for species distribution modelling (MaxEnt ver. 3.4.1; Phillips, Anderson \& Schapire, 2006; Phillips, Dudík \& Schapire, 2017). MaxEnt is a learning machine method, which uses presence only data in combination with predictive variables to model a species' geographic distribution. Several studies have demonstrated that MaxEnt performs well at predicting species geographic distributions, and it has shown better performance and predictive ability when compared to other niche-modeling techniques (e.g., Duque-Lazo et al., 2016; Bueno et al., 2017). We used climatic layers obtained from WorldClim (ver. 2) as predictive variables in our model (http://worldclim.org/version2; Fick \& Hijmans, 2017). These 
variables are derived from monthly temperature and rainfall values that represent annual trends, seasonality and extreme or limiting environmental factors (Hijmans et al., 2005). For our models, we selected temperature seasonality (BIO4), maximum temperature of the warmest month (BIO5), minimum temperature of the coldest month (BIO6), precipitation of the wettest month (BIO13), precipitation of the driest month (BIO14) and precipitation seasonality (BIO15) as climatic variables because they represent the extreme limiting climatic factors and their variation. The calibration area was defined as the smallest rectangle that encompassed all the location records that we used for the model plus $10 \mathrm{~km}$, and restricted to the subtropics in the Americas (minimum and maximum latitude $-30-30^{\circ}$; Corlett, 2013). For presence records, we used the georeferenced and validated locations that we obtained from the different sources listed above, after eliminating duplicates and setting a minimum distance of $1.5 \mathrm{~km}$ between occurrence records (to prevent model overfitting due to similar climatic conditions of adjacent points). We randomly selected $20 \%$ of the points to test the performance of the model, and performed 10 replicates. To evaluate the performance of the model, we used the AUC statistics (area under the receiver operating characteristic curve), which provides a single measure of the model performance (Phillips, Anderson \& Schapire, 2006). Models that have an excellent predictive performance have AUC values $>0.90$, 0.80-0.90 are considered to have good predictive performance, while models with AUC values $<0.70$ are considered poor (Swets, 1988; Manel, Williams \& Ormerod, 2001; Franklin, 2010). To determine the presence-absence threshold, we used the Maximum Training Specificity plus Sensitivity threshold, which minimizes the mean of the error rate for positive and negative observations (Manel, Williams \& Ormerod, 2001; Freeman 
\& Moisen, 2008), and performs better than other thresholds in providing accurate presence predictions (Liu et al., 2005; Jiménez-Valverde \& Lobo, 2007; Freeman \& Moisen, 2008).

Ecology of Brotogeris versicolurus in Puerto Rico

Brotogeris (Psittacidae) is a small genus (7-8 spp.) of highly abundant Neotropical parakeet species (Juniper \& Parr, 1998; Forshaw, 2010), occupying varied habitats from dry savannas to tropical rain forests (del Hoyo, Elliott \& Sargatal, 1997). Some of these species, if not all, have been harvested to supply the demands of the pet trade market, which is likely to have resulted in population reduction in their native habitat, while some of these species have had their populations reduced as a consequence of habitat destruction (e.g., B. phyrrhoptera; Birdlife International, 2016).

The white-winged parakeet is considered a widespread species in its native range of South America, occupying French Guiana, the Amazon basin from the north of Brazil to the south-east of Colombia, east of Ecuador, north of Argentina and Paraguay and the south-east of Brazil (Forshaw, 1973). Its non-native range includes Ecuador (west of Los Andes, Freile et al., 2012) California (Arrowood, 1981), and Florida (Juniper \& Parr, 1998; Forshaw, 2010). Moreover, in 1969, Kepler made the first report of feral whitewinged parakeets in Puerto Rico, in the area of Luquillo (Bond, 1971), and since, others have reported its presence and persistence (Pérez-Rivera et al., 1985; Raffaele, 1989; Camacho-Rodríguez, Chabert-Llompart \& López-Flores, 1999). This parakeet is considered mainly a frugivorous species, although they may also use nectar and seeds as part of their diet (Janzen, 1981; Pérez-Rivera et al., 1985; Francisco, Lunardi \& Galetti, 2002). 
Many species of the Psittacidae family, including B. versicolurus roosts communally (Juniper \& Parr, 1998; Brightsmith et al., 2017). The white-winged parakeet nests in arboreal termite mounds and sometimes in tree cavities (Pérez-Rivera et al., 1985). Moreover, we observed that in Puerto Rico, a proportion of the roosting population presumably break up into pairs and breed from late December to June and then eventually join the non-breeding, roosting proportion of the population. This was confirmed by Tossas, Colón \& Sanders (2012) in a population in San Germán, and has also been reported in the native range (Forshaw, 1973; Juniper \& Parr, 1998). In the continental U.S., fledglings have been reported to stay with the parents and return to the roosting sites after the breeding season (Schroads, 1974; Arrowood, 1981). In California, the parakeets have shown roosting site fidelity (Arrowood, 1981), and in Florida, seasonal and annual shifts in roost sites have been reported (Schroads, 1974). The birds were not marked in any of the studies, so it is impossible to determine if this involves the same individuals across time (Brightsmith et al., 2017). During the study period, we recorded observations on natural history information about the food and nest resources (plant species) used by the white-winged parakeet, and also extracted information from Pérez-Rivera et al. (1985).

To estimate the roosting population size, we used the Roost Count Method (Chapman, Chapman \& Lefebvre, 1989; Gnam \& Burchsted, 1991; Pithon \& Dytham, 1999; Tossas, Colón \& Sanders, 2012). We identified roosting sites for each population during the non-breeding season, following flocks before dusk. Then we identified areas from which the birds could be readily observed entering or leaving the roosting area. The monitoring period started from dawn in Guaynabo and before dusk in San Germán, and 
stopped after 20 minutes with no birds departing or entering the roost area. Since the birds gather in flocks and fly in different directions from or to the roosting area, each observer counted birds flying out of or into the roosting area in different directions to avoid double counting. If any flock returned to- (San Patricio) or left the- (San Germán) roosting area it was subtracted from the count values, as they would ultimately depart from the area again, thus avoiding double counting. We used SLR cameras with telephoto lens $(70-300 \mathrm{~mm})$ to photograph the flocks and then count the quantity of individuals for large flocks ( $>16$ individuals) from the photos. Days with bad weather which resulted in difficulty in counting the birds were avoided and counts were repeated if necessary. Nonbreeding counts (representing the minimum population size) in Guaynabo were conducted in September of each year (2007-2009, but on 2010 it was conducted in November due to rains), and the counts in San Germán were conducted in October of each year (2007-2010). In 2010, we performed breeding counts during late March (midlate breeding season) in both roosting populations to estimate the proportion of breeding birds.

The Roost Count Method was evaluated along with Point Transects, Line Transects and mark-recapture, using the green-rumped parrolets (Forpus passerines), and the four methods produced $95 \%$ confidence intervals that overlapped and similar population estimates (Casagrande \& Beissinger, 1997). To test the effectiveness of this method with the white-winged parakeet, we conducted three counts spaced a week between them from September to October 2007 in the Guaynabo population, and the population estimates exhibited low variability (range: $1,164-1,299 \pm 72 \mathrm{SD})$.

For the population estimates, and to calculate the population growth rates, we 
assumed that 1) all the parakeets roosted communally during de non-breeding season and that during the breeding season, only non-reproductive parakeets roosted communally, 2) the parakeets returned to roost in the same area after the breeding season, 3) the counts that were performed during the non-breeding season reflected the population size after mortality and emigration events shortly after the breeding season (these cannot be separated with this method), and 4) the number of parakeets counted in each roost is accurate, and 5) the estimated population size represents the minimum number of parakeets in the roost.

We calculated the population growth rates using the equation for exponential growth in populations with overlapping generations (Rockwood, 2006) re-arranged as $r=\left[\ln \left(N_{t} / N_{0}\right)\right] / t$ to get the $r$ values, where:

$r$ is the intrinsic rate of increase;

$N_{t}$ is the population size at time $t$;

$N_{0}$ is the initial population size;

$t$ is the time in years

This model assumes that 1) the population has overlapping generations and that 2) the population exhibits a stable age structure. In this model, the population grows if $r>0$, decreases if $r<0$ and is stationary if $r=0$. We then converted the $r$ values to the finite rate of increase per $\mathrm{yr}, \lambda$, with the equation $\lambda=e^{r}$. When $\lambda<1$ the population decreases, the population is stable if $\lambda=1$ and the population increases if $\lambda>1$.

To determine the proportion of the breeding population, we subtracted the number of parakeets counted during the breeding censuses of 2010 from the population estimates of the 2009 non-breeding censuses. Since both adults have been reported to roost in the 
nest until all the chicks are fledged (Schroads, 1974), we divided the total number of breeding individuals by two to get the approximate number of breeding pairs.

\section{Statistical analyses and data visualization}

We performed all data pre-processing, obtained summary statistics, and visualizations using R ver. 3.3.3 (R Core Team, 2017), and packages 'ggplot2' (Wickham, 2016), 'raster'(Hijmans, 2017), 'zoo' (Zeileis \& Grothendieck, 2005), 'plyr' (Wickham, 2011), and the output from MaxEnt. We mapped occurrence records and visualized distribution results using QGIS ver. 2.18.14-Las Palmas de G. C. (QGIS Development Team, 2017).

\section{Results}

\section{Introductions of Psittaciformes to Puerto Rico}

Historical and current status of Psittaciformes.- We found historical records for 18 species of Psittaciformes reported by the year 2000, with eight of those breeding. On the other hand, we found that at least 46 species of Psittaciformes are currently present on the island (Fig. 1; Table 1), of which $24 \%$ are only found in the pet trade, $48 \%$ have been observed in the wild (present), but are probably not established, and $28 \%$ are established and known to have been or be currently breeding (Table 1). At least $85 \%$ of the species are currently available for sale in the pet trade. Of the 46 species of Psittaciformes found in Puerto Rico, at least 63\% have been reported in the wild elsewhere (but it is unknown whether they are breeding), and 26\% are considered as established or invasive (i.e., breeding outside their native range and expanding their territory, but not necessarily causing negative impacts). 
Sighting trends of Psittaciformes in Puerto Rico.- We found sufficient reports to calculate the island-wide sighting trends for 10 species of Psittaciformes in Puerto Rico (Fig. 2-3). Four species exhibited population increase, three species showed stable populations, and three species exhibited population decrease. For the rest of the species, the count numbers were too low and/or temporal resolution was too short to calculate trends. Of the species with population increase, the white-winged parakeet showed the largest population increase (Fig. 3), followed by the monk parakeet (Myiopsitta monachus), the red-masked conure (Psittacara. (Aratinga) erythrogenys) and the orangefronted parakeet (Eupsittula canicularis; Fig. 2). The orange winged amazon (Amazona amazonica) showed a population increase and later stabilized, while the white-crested cockatoo (Cacatua alba) showed a stable population trend, albeit with low numbers. The blue-and-yellow macaw (Ara aranaura) exhibited a decrease from 1996 to 2002 (with up to 22 individuals reported) in the Metropolitan Area of San Juan, and later recovered and stabilized with about 14 individuals. The green-checked amazon (Amazona viridigenalis) showed a steep decrease after reaching a total of 53 individuals per mean count/municipality/year, with low counts after 2006. Similar trends were observed in the white-fronted amazon (A. albifrons), but in much lower numbers. Finally, the rose-ringed parakeet (Psittacula krameri) showed a sustained decrease after a maximum of 11 individuals were reported in 2011.

Distribution of Psittaciformes in Puerto Rico.- Overall, we obtained 6,905 locality records for 26 species of Psittaciformes in the wild that spanned from 1960 to 2017 (in 
Ebird; see electronic supplementary information S1 for detailed species-specific results and S2 for location records). Moreover, we obtained 279 sighting records for 10 species from local groups (see electronic supplementary information S3 for links to speciesspecific reports). Sightings and reports of Psittaciformes in Puerto Rico practically cover the whole island, and are especially dense in coastal and highly (human) populated areas (Fig. 4), but the geographic extent of the distribution varies by species (see electronic supplementary information S4 for the distribution of locations for each species reported in the island).

More specifically, for the white-winged parakeet, the different locality record sources yielded a total of 2,520 occurrence records in Puerto Rico. Historic reports on the distribution of $B$. versicolurus show that parakeets were present in Luquillo (east) in small numbers by the 1960's (Kepler in Bond 1971). Moreover, a small population was found breeding in the municipality of Naguabo (east) and about 360 individuals were reported in Guaynabo by 1985, were the San Patricio population is presently located (Fig. 5; Pérez-Rivera et al., 1985). Furthermore, the only other historic record are from the population in San Germán, which was estimated at 800 individuals by 1995 (CamachoRodríguez, Chabert-Llompart \& López-Flores, 1999). Since then, the parakeet populations have expanded significantly throughout the island, especially to coastal and heavily (human) populated zones, but they have also been occasionally observed in the central mountainous regions (Fig. 5).

For predicting the potential distribution of the psittacine species whose populations are increasing in Puerto Rico, we obtained a total of occurrence 106,493 records from their native range and from their invasive range (including Puerto Rico; see electronic 
supplementary information S2). Our models performed good to excellent, with test AUC values ranging from $0.82-0.94$ (Table 2), and the presence records for the four species are within the predicted distribution in its native range, indicating a good model fit.

Furthermore, the models predicted suitable areas for all four species in Puerto Rico (Fig. 5).

The predicted distribution for the white-winged parakeet in Puerto Rico showed the highest suitable areas in the north-central part of the island, but also included the other coastal areas. Only in the central and central-west part of the island, where the Central Cordillera occurs, did MaxEnt predicted unsuitable areas for the species. In general, $B$. versicolurus occupies virtually all the areas with the highest suitability. Similar areas were predicted with suitable climatic conditions for the monk parakeet, although there are areas in the west of the island predicted as unsuitable where the monk parakeet has been reported. The models also predicted suitable areas for the red-masked conure and the orange-fronted parakeet, some of which they occupy. Both species have lower predicted climatic suitability than white-winged and monk parakeets, and the orange-fronted parakeet has a smaller predicted suitable area than the other species. In general, our models predicted suitable areas outside the current range of all four species, indicating the possibility for further range expansion.

\section{Ecology of Brotogeris versicolurus in Puerto Rico}

During the study period, we made observations on the diet of the white-winged parakeet in the Metropolitan Area of San Juan. They use mostly exotic species of plants as food resources, and as in their native range, they are primarily frugivorous, but also consume flowers, seeds and sap (Table 3; complimented with data from Pérez-Rivera et al., 1985). 
The annual breeding cycle of the white-winged parakeet in the Metropolitan Area of San Juan starts in January, at the end of the dry season, with reproductive pairs starting to inspect possible nests, and continues through February with pairs constructing their nests. They may use new termite mounds, or re-use termite mounds used in previous years for nesting. Between February and April, reproductive pairs nest and raise their chicks while non-reproductive parakeets presumably stay at the roosting sites. Most chicks are fledged by June, and presumably join the roosting parakeets along with their parents. In terms of nesting, although there were tree cavities likely suitable for the white-winged parakeets in some places where nesting occurred, all nest we found were constructed in termite mounds of Nasutitermes sp. in native and exotic trees (Table 3). Two nests inspected with a pipe inspection camera revealed one clutch of three eggs and one clutch of four eggs. Moreover, five nests inspected with the same method revealed a mean of $2.14( \pm 0.69)$ chicks per nest. Furthermore, upon inspection of a chick that fell from another nest, we found feather mites (Acarina), likely of the genus Pararalichus.

The San Germán population of white-winged parakeets increased from 1,503 birds in 2007 to 3,010 birds in 2010. However, although the San Patricio population was steadily increasing from 2007-2009, from 1,299 to 3,128 individuals, a population decline occurred in 2010, and the population was reduced to 2,531 individuals (Fig. 3). Both populations exhibited overall positive population growth rates, with a geometric mean $\lambda=1.24( \pm 0.48)$ in San Patricio, and $\lambda=1.26( \pm 0.08)$ in San Germán during the study period (Table 4). If we consider the population estimates prior and after to our population estimates (a period of 29 yr in San Patricio, and 40 yr in San Germán), both populations exhibited $\lambda$ s of 1.20 and 1.17 , respectively. Moreover, the island-wide sum of 
the mean counts per municipality shows an increase of birds from 9 parakeets in 1985 to 375 parakeets in 2017 among 55 of the 78 municipalities in Puerto Rico (Fig. 3). Based on the breeding census, we estimated that $40 \%$ of the population at San Patricio was breeding (625 pairs), and $42 \%$ of the population at San Germán (512 pairs). Based on the number of birds retuning to the roost after the breeding season, the number of fledglings (recruitment) was estimated in 604 for San Germán (assuming 2 chicks per pair), but because of the population decline, it was not possible to estimate this for the San Patricio population.

\section{Discussion}

\section{Introductions of psittaciformes to Puerto Rico}

In this study, we sought to assess the status of non-native Psittaciformes in Puerto Rico, and the invasive ecology of the white-winged parakeet. We found a total of 46 psittacine species present on the island. Of the 8 species historically reported as established (breeding) in the wild, we confirmed that six still persist, and at least nine species are currently breeding (11 if we consider all species breeding at any given time throughout the historical survey). Moreover, we found clear evidence of invasiveness for the whitewinged parakeets, and sighting trends and observation suggest the same for monk parakeets. To our knowledge, Puerto Rico is the place with the highest number of wild observed and established exotic parrot species in the world based on surveys in other places where parrot populations occur (e.g., (Runde, Pitt \& Foster, 2007; Mori et al., 2013; Symes, 2014).

Introduction of Psittasiformes to Puerto Rico have been solely via the pet trade. 
According to Forshaw (1973), the Hispaniola amazon apparently was introduced to Puerto Rico because managing agencies refused to give the importation permits for a shipment brought from the Dominican Republic by boat, which resulted in the deliberate release of 'hundreds' of parrots. The Hispaniola amazon is currently established and breeding in Mayagüez, but their numbers appear to be low ( $\sim 10$ individuals; WF, pers. obs.). It is unknown whether the present population is the result of the release reported by Forshaw (1973) and/or the subsequent release of pet parrots into the wild. However, most Psittaciformes observed and/or established in the wild in Puerto Rico are believed to be the result of intentional or accidental releases by owners who bought them through the pet trade. For example, Pérez-Rivera (1985) made the first report of 10 individuals of the red-masked conure in Cataño. We are unaware of any existing populations of this conure in Cataño, but close-by in Río Piedras (San Juan), a population of about 20 individuals have been known since 2010 and are breeding, using cavities in buildings of the University of Puerto Rico as nests (WF pers. obs.), and there are reports of 30 individuals in the nearby Guaynabo municipality (adjacent to San Juan and Cataño municipalities). Moreover, there is a population established in the municipality of Arecibo (northcentral), with over 50 individuals reported. However, not all introduced species succeeded, for example, a 'small group' of masked lovebirds (Agapornis personata) was reported in Caguas between 1982-1984 (Pérez-Rivera 1985). No details were provided on whether the population was breeding or not. Based on the occurrence records obtained, and our observations, this species is currently absent in the wild in Puerto Rico, thus it is highly probable that this flock went extinct.

Observations on flock size and sighting trends of Psittaciformes in Puerto Rico 
indicate that the different species are experiencing different dynamics. For example, white-winged (discussed below in more detail) and monk parakeets are the only two species that appear to be growing exponentially. Records for the monk parakeets started in 1979 throughout coastal and densely populated (humans) areas (mainly San Juan and Ponce), and by 1987, flocks of up to 30 individuals were observed. By the late 1990's sightings outside these two municipalities started, and became more common throughout the island as time passed probably as a result of population growth and range expansion. The orange-winged amazons exhibited an increase in sightings since the 1990's, and by 2014, the population seemed to be stabilized. The maximum number of individuals reported is 39 , but there is a population roosting in the municipality of Morovis with over 100 individuals (not included in the count data; J. Salgado Vélez, pers. comm.). Moreover, the orange-winged amazons are the most widespread of the amazon parrots in Puerto Rico. The blue-and-yellow macaws apparently experienced a population decline in the Metropolitan Area of San Juan, and later increased and stabilized. Furthermore, a population of at least 15 individuals is breeding in the municipality of Orocovis, $\sim 29 \mathrm{~km}$ away from the other population (not included in count data), and some have been sighted in Cabo Rojo (west of the island). The sighting trends of the white-crested cockatoo seems to indicate the population is stable with low numbers (2-15 individual), and localized in the adjacent municipalities of Bayamón and Guaynabo in the Metropolitan Area. Interestingly, the green- and white-fronted amazons exhibited a sighting decline after initially increasing. The green-fronted amazon has two reported populations; one in the municipality of Mayagüez (west) with up to 10 individuals recorded, and one in the municipality of Salinas (southeast) with up to 30 individuals recorded. Similarly, the 
white-fronted amazon, which is restricted to Mayagüez, exhibited a reduction in sightings, from up to 11 individuals in 2011, to $1-2$ individuals in recent years. Moreover, although uncommon, there have been reports of rose-ringed parakeet in Puerto Rico, and at least 12 individuals recorded in Aguadilla in 2012. However, their sighting trends indicate a decrease in numbers, so it's possible that the group failed to establish, and the recent reports are of escaped pets. However, rose-ringed parakeets can easily be obtained through the online pet market, and has become more popular as a pet in recent years. Therefore, more releases are possible, and the possibility of rose-ringed parakeets establishing in Puerto Rico is latent.

Psittaciformes in Puerto Rico are more commonly distributed along the coastal region, and areas with the highest occurrence records coincide with densely populated areas by humans, especially the Metropolitan Area of San Juan. However, the location and the extent of the geographic distribution of Psittaciformes varies between species. The most recorded and widespread species are those whose population trends (based on sightings) seem to be increasing, and their current distribution coincide with areas predicted to be climatically suitable. Moreover, suitable areas are present outside the areas where these different species occur, indicating the potential for continued range expansion. Of these, the white-winged and the monk parakeets are undoubtedly the most sighted and widespread species of Psittaciformes in Puerto Rico.

Perhaps the most important factor promoting the success of Psittaciformes outside their native range is the sheer number of individuals that were and are available through the pet trade. Invasion success for exotic bird species is positively influenced by the number of individuals available on the market (Carrete \& Tella, 2008), and species more 
commonly found in captivity, and that tend to be cheaper, have a higher probability of being introduced into the wild (Robinson, 2001; Cassey et al., 2004b; Blackburn, Lockwood \& Cassey, 2009). In general, among bird species, Psittaciformes have a high probability of transport and introduction outside their native range (Lockwood, 1999; Lockwood, Brooks \& McKinney, 2000; Blackburn \& Duncan, 2001; Duncan, Blackburn \& Cassey, 2006), being traded as much as 14 times more often than other avian orders (Bush, Baker \& MacDonald, 2014). Moreover, parrots in general have a wide diet breath, and research suggests that diet breath and migratory tendencies can explain the success of established exotic populations of parrots (Cassey et al., 2004a). Consequently, 10-16\% of all parrot species have established exotic populations around the world (Cassey et al., 2004b; Menchetti \& Mori, 2014).

As with any introduced invasive species, there are concerns over the possible negative impacts that exotic parrots may have on the economy and the native ecosystems (Pérez-Rivera \& Vélez-Miranda, 1980), which has been recently reviewed by Menchetti \& Mori (2014). These include damage to crops, damage to the electrical infrastructure, transmission of diseases, competition, and hybridization. Damage to crops is perhaps the biggest negative impact that parrots cause in both their native and introduced range, with substantial economic losses (e.g., González, 2003). In addition, in Florida (USA), monk parakeets have been reported to cause electric shortages while building nests in electric towers, costing as much as USD 585,000 for repairs (Avery et al., 2006). To our knowledge, the only invasive species that has caused electrical shortages in Puerto Rico has been the invasive green iguana (Iguana iguana; Falcón et al., 2013), and we have not observed nests of monk parakeets in electrical towers. Moreover, wild and captive 
Psittaciformes are known vectors of avian and diseases and parasites, and also human diseases (Clark, Hume \& Hayes, 1988; Orosz et al., 1992; Magnino et al., 1996; Mase et al., 2001; Azevedo, 2014; Done \& Tamura, 2014; Briceno et al., 2017). In terms of competition, antagonistic interactions have been reported in parks and urbanized areas where introduced parrots aggressively displace native birds at garden feeders, they can consume unripe fruits before other native birds have access to them (because native species only eat them when they are ripe; Snyder, Wieley \& Kepler, 2007; Lin Neo, 2012; Le Louarn et al., 2016). Competition for cavities, on the other hand, may be a cause of concern, because there are native species which depend on this scarce resource, and psittacine secondary cavity nesters can be aggressive competitor (Snyder, Wieley \& Kepler, 2007; Strubbe \& Matthysen, 2009a; Orchan et al., 2012; Mori et al., 2017). However, populations of cavity nesters (e.g., Amazona spp and rose-ringed parakeets) are relatively low, and the most successful psittacine species in Puerto Rico build their own nests. Finally, based on the distribution of Amazona spp. in Puerto Rico, hybridization with the endemic Puerto Rican amazon is unlikely at the moment, but it is a latent possibility as both endemic and introduced populations continue to grow and expand their range. For example, Amazona oratrix and A. aestiva are known to hybridize in the wild when they co-occur (in their introduced range; Martens, Hoppe \& Woog, 2013).

Another aspect to consider is that the three species of endemic parrots in Puerto Rico were once much more common and used to occupy many of the areas and habitats now occupied by exotic species. In fact, the extinct Puerto Rican parakeet (Psittacara maugei) was so abundant and widespread that it was, in part, hunted down to extinction because of the damages it caused to the agricultural sector (Olson, 2015), as was the 
Carolina parakeet (Saikku, 1990). Thus, the dramatic population decrease and range reduction of the Puerto Rican parrot, as well as the extinction of the other endemic parrot and parakeet left empty niches. Perhaps one of the most important functions performed by the endemic parrots were seed predation and seed dispersal. Parrots are known to incur in such functions (Norconk, Grafton \& Conklin Brittain, 1998; Francisco, Lunardi \& Galetti, 2002; Blanco et al., 2015; 2016; Blanco, Hiraldo \& Tella, 2017), and both seed predation and seed dispersal have important implications for ecosystems dynamics worldwide, and help regulate plant recruitment, competition, and population structure (Howe \& Smallwood, 1982; Hamrick, Murawski \& Nason, 1993; Nathan \& MullerLandau, 2000). Unlike other birds, parrots have specialized bills that allows them to access resources, such as hard seeds, that are often not available to other animals, and they often predate on them in the wild. For example, the white-winged parakeet is a seed predator of the Panama tree (Sterculia apetala), an introduced species in Puerto Rico. But they also predate seeds of the pink trumpet tree (Tabebuia heterophylla), an abundant native species on the island. Likewise, blue-and-yellow macaws predate on the seeds of Swietenia spp., which are exotic trees whose seeds are too large for other species of birds. On the other hand, as generalist frugivores, parrots also act as seed dispersers via endozoochory (Blanco et al., 2016). For example, white-winged parakeets are known to disperse Ficus spp., which are small- and hard-seeded plants (WF, pers. obs.). Research should focus on the ecological role of introduced psittacine species in order to assess the impacts, neutral, positive and/or negative, that they are having in their introduced range. Currently, no species of Psittaciformes is considered illegal in Puerto Rico by the Department of Natural and Environmental Resources (Departamento de Recursos 
Naturales y Ambientales de Puerto Rico, 2003). Trapping of exotic birds established in Puerto Rico is allowed by the DNER for exportation only, and the sale in local markets is prohibited. A permit is required for trapping and exporting birds, and a report must be filed at the end of the activity. We had access to such reports from the DNER, and the most commonly trapped bird was the white-winged parakeet. However, rarely the number of individuals trapped was reported. Moreover, information about the exportation process is not provided. We recommend that the DNER adjusts the protocol and collects detailed information about the locality of trapping, quantity and species of birds trapped, and the final destination of the birds. Such information may provide insights into how harvesting affects the population growth of these birds and therefore have management implications.

Although selling some of the wild trapped species of parrots in the local pet market is illegal, it is common to find people selling them, especially on the internet. Particularly common are budgerigars, lovebirds, white-winged parakeets and monk parakeets. The rose-ringed parakeet is gaining popularity and it is relatively easy to acquire them.

Therefore, we recommend that management agencies should prohibit or limit the sale and possession of psittacine species that are prone to establish outside their native range, and focus on the trade of Psittaciformes (and other species) in order to prevent more escapes and thus control propagule pressure and range expansion via introductions to new areas.

If control and management is necessary and/or desirable, there are several methods available. Public education about the potential effects of releasing exotic animals, and breeding controls are important for preventing releases into the wild. When direct management is necessary, there are three options: 1) trapping and exporting birds, 2) birth control chemosterilants such as Diazacon ${ }^{\mathrm{TM}}$ (Yoder et al., 2007; Avery, Yoder \& Tillman, 
2008; Lambert et al., 2010), and 3) culling (lethal). However, control efforts, especially lethal ones, may be hindered by members of the public, who usually protest these actions as parrots have a high aesthetic value (Avery \& Tillman, 2005).

\section{Ecology of Brotogeris versicolurus in Puerto Rico}

Diet observation of the white-winged parakeet coincide with previous reports on the island (Pérez-Rivera et al., 1985), are consistent to those reported elsewhere in their invasive and native range (Brightsmith et al., 2017), and show that although they use native species, the majority of the plant species consumed are exotic ones. Nesting phenology observations in the Metropolitan Area of San Juan are consistent with the findings of the population in San Germán (Tossas, Colón \& Sanders, 2012), and in Florida (Brightsmith et al., 2017). Moreover, we found an unidentified species of mite (probably Pararalichus), which has been reported on B. versocolurus in its native range, along with Aralichus cribiformes and Echinofemur sp. and Rhytidelasma sp. (Atyeo, 1989). In most cases, transfer of mites occur by physical contact between conspecifics, but there are cases of inter-species transfer (Dabert \& Mironov, 1999; Hernandes, Valim \& Pedroso, 2016). However, these, as most feather mites, are considered ectocommensals and feed on the oils produced by the birds (Blanco et al., 2001).

Calculating the population growth rate based on the population size estimate of Tossas, Colón \& Sanders (2012) and our first population estimate yields results of positive growth rate consistent with those found during our study period. Comparing the historic number of parakeets in the study populations with data from this study, and their population growth rates, suggest that the population exhibited a lag-phase, and was growing exponentially by 2010 . 
The resulting population decrease in 2010 was probably due to emigration and the establishment of a new roosting site in the Río Piedras Botanical Garden, where parakeets would forage, but did not roosted before $(5.6 \mathrm{~km}$ from the San Patricio roosting site). Around 800 parakeets were seen roosting at this new location. If we assume that the parakeets at the new roosting site originated from the San Patricio population, then a minimum of 200 fledglings were produced (considerably lower than the production in San Germán), and about 300 pairs abandoned the San Patricio roost. Another roosting site was established in 2012 at the University of Puerto Rico, $5.5 \mathrm{~km}$ from San Patricio, and $1.5 \mathrm{~km}$ from the Botanical Garden population.

Population growth rates of species of birds regarded as invasive are usually exponential, and often exhibit a lag-phase (Sakai et al., 2001; Blackburn, Lockwood \& Cassey, 2009) and we have observed both of these patterns in the Puerto Rican populations of B. versicolurus (and M. monachus). Exotic species that exhibit high population growth rates may be more likely to establish viable populations (Ehrlich, 1986; Moulton \& Pimm, 1986; Pimm, Jones \& Diamond, 1988; Pimm, 1989; Cassey, 2001). Additionally, as the size of species population increases, so does the geographic distribution, so we can expect that population growth will probably result in spread (although this is not always the case; Gaston et al., 2003; Gaston, 2003; Blackburn, Cassey \& Gaston, 2006). Indeed, in the yellow-headed blackbird (Xanthocephalus xanthocephalus), a native species in the USA, the eastward dispersal of the species was linked with the population growth rate (Veit, 1997). It has been proposed that populations of birds exhibiting a positive population growth rate have a proportional increase of long dispersers (vagrants) to the increase in population size and thus, incrementing the chances 
of the species invading new ranges (Veit, 1997; 2000). Our data and observations suggest that the rapid increase and high number of parakeets in the San Patricio population led to the emigration and establishment of new roosts, therefore expanding their range. This is supported by the lag between population increase at the largest roosting sites on the island, and the island-wide population increase.

Migration to and from the roosting sites is a factor that can affect our population growth estimates, and bias our results since we are not considering migration and we assume that the changes in populations are due to birth and death rates. Our surveys in the vicinity of both study populations suggested that they were they only existing roosting sites in the areas, a fact that was confirmed by Tossas, Colón \& Sanders (2012) for the San Germán population. During our surveys, we were able to detect the establishment of a new roosting site, which probably originated from the San Patricio population, so emigration is a factor regulating population size. Although white-winged parakeets can exhibit yearly variations in terms of the number of individuals at the roost site, the variation is low within the peak of the breeding and non-breeding seasons (Tossas, Colón \& Sanders, 2012), as confirmed by our weekly estimates. Given this, and that we were able to detect the establishment of the new roosting site, which likely explains the population decline in San Patricio, we are confident that our methods and estimates are robust.

Various factors may have contributed to the success of white-winged parakeets in Puerto Rico. Firstly, propagule pressure may have been an important factor leading to the introduction and establishment during the 1960's and 1980's, when they were popular and cheap. According to the CITES Trade Database, the main exporter to the USA (and 
therefore Puerto Rico) was Peru, with 2,832 white-winged parakeets exported in a single shipment in 1985. Moreover, because they nest in termite mounds, which are highly abundant in the secondary forests of Puerto Rico and parks, white-winged parakeets are not limited by the scarcity of tree cavities as in other parrot species. In addition, no predation observation have been made, indicating that predation pressure is low, and the potential predator pool is rather small (including Falco peregrinus, F. columbarius, $F$. sparverius, Acipiter striatus and A. cooperii; Brightsmith et al., 2017). Furthermore, trapping seems to supply the local (informal) pet market, rather than serving for exportation, further exacerbating releases into the wild. Finally, the white-winged parakeet seems to have a wide diet breath.

\section{Conclusions}

Our data shows that most Psittaciformes introduced through the pet trade to Puerto Rico, and that established populations, are still present and persist in the wild. Based on population sizes and range, white-winged parakeets and monk parakeets are indeed the most successful Psittaciformes in Puerto Rico. The data suggest that white-winged parakeets are very prolific, are aggressively expanding their range, especially in coastal areas, and we expect them to keep growing exponentially and expanding into new, unoccupied areas. The same is probably true for monk parakeets. A species of special concern is the rose-ringed parakeet (Psittacula krameri). This species is highly invasive elsewhere, and has caused negative ecological impacts (Butler, 2003; Strubbe \& Matthysen, 2009a,b; Kumschick \& Nentwig, 2010; Newson et al., 2011; Sa et al., 2014; Le Louarn et al., 2016). Therefore, special attention should be given to this species, and others that have invasiveness potential, with the aims of preventing the sale and 
possession and ultimately prevent releases to the wild and subsequent establishment.

Although unlikely at the moment, as populations of the endemic and endangered Puerto Rican parrot increase in size and distribution, it is likely that they will interact with exotic species. Thus, special consideration and management priority should be given to species with populations established near wild populations of Puerto Rican parrots, especially other Amazona spp., to prevent competition for food and nesting resources, hybridization and transmission of diseases.

It is worth mentioning that in late 2017 Hurricane María, a category four hurricane, hit Puerto Rico with a south-to-north trajectory, and undoubtedly caused negative impacts on the parrot populations in the island. For example, dozens of dead white-winged parakeets were observed around a recent roost located in Río Piedras (municipality of San Juan; Fig. 1f), and at least one blue-and-yellow macaw was found dead in Guaynabo. Despite this, numerous flocks of parakeets and at least eight macaws were seen after the hurricane, so a proportion of individuals of these species survived. It is highly possible that other parrots experienced mortality related to the hurricane. Indeed, the endemic Puerto Rican parrot suffered very high hurricane-related losses in the east of the island ( $\mathrm{R}$ Valentín, pers. comm.). Another negative effect as a result of the hurricane is the lack of food resources due to the massive exfoliation of food plants. For example, blue-andyellow macaws, which usually forage high on trees and palms, were observed eating flowers on shrubs as low as $1.5 \mathrm{~m}$ from the ground due to the lack of food. A follow-up study on the status of Psittaciformes after the hurricane is recommended, as it is possible that the negative effects may result in the extirpation of some of the species, especially those with small population sizes. 
Finally, many of the species of Psittaciformes found in the wild in Puerto Rico are vulnerable or endangered in their native range, and introduced populations provide the opportunity to conduct experiments and/or to explore management techniques that otherwise would be impossible to perform in their native habitat, both aspects which may aid in the conservation of Psittaciformes in their native habitat around the world.

\section{Acknowledgements}

We want to especially thank Rafael D. Rodríguez, Linda Ortíz and Rebecca Hernández for their help in the field during the white-winged parakeet roost counts. We also thank Marilyn Colón of the DNER, for her help during permit application process, and for providing unpublished reports on exotic bird trapping in Puerto Rico, and Ricardo Valentín of the DNER for sharing information about the state of the Puerto Rican Parrot after Hurricane Maria. We also thank and Noramil Herrera, and Alberto Mercado (DNER) for helping in the search of literature resources. Julio A. Salgado of the Puerto Rico Ornithological Society provided assistance in sharing the online form for reporting Psittaciformes in Puerto Rico among different local groups, and also provided information on the current status of psittacine birds on the island, and photos, for which we are extremely grateful. We also thank Yoly Pereira, Pedro Santana, Sonia Longoria, and Dinath Figueroa for allowing us to use their photos. The PR-Louis Stokes Alliance for Minority Participation Bridge to the Doctorate Fellowship (HRD-0601843), the Ronald E. McNair Program of the University of Puerto Rico at Humacao (P217A070213), and the Center for Applied Tropical Ecology and Conservation (HRD0734826) provided funding to WF in partial support of this project. 


\section{References}

Arrowood PC 1981. Importation and status of canary-winged parakeets (Brotogeris versicolurus) in California. In: Pasquier RF ed. Conservation of New World parrots. Washington D.C., 425-429.

Atyeo WT 1989. Aralichus porrectus (Mégnin \& Trouessart) and related feather mite species (Acarina, Pterolichidae) from parrots of the genus Brotogeris Vigors (Aves, Psittacidae). Systematic Parasitology 14:101-111. DOI: 10.1007/BF00016904.

Avery M, Tillman E 2005. Alien birds in North America: Challenges for wildlife managers. In: Nolte DL, Fagerstone KA eds. 82-89.

Avery ML, Lindsay JR, Newman JR, Pruett-Jones S, Tilman E 2006. Reducing Monk parakeet impacts to electric utility facilities in South Florida. In: Feare CJ, Cowan DP eds. Advances in Vertebrate Pest Management IV. Furth, 125-136.

Avery ML, Yoder CA, Tillman EA 2008. Diazacon inhibits reproduction in invasive monk parakeet populations. Journal of Wildlife Management 72:1449-1452. DOI: 10.2193/2007-391.

Azevedo NP 2014. Detection of Avian Bornavirus, Polyomavirus and Circovirus in biological samples, using PCR and RT-PCR technique, from psittacine bird with different clinical manifestation. Faculdade de Medicina Veterinária e Zootecnia, Universidade de São Paulo. DOI: 10.11606/D.10.2014.tde-07102014-152516.

Birdlife International 2016.Brotogeris pyrrhoptera. The IUCN Red List of Threatened Species e.T22685966A93094507. Available at http://dx.doi.org/10.2305/IUCN.UK.2016-3.RLTS.T22685966A93094507.en (accessed December, 2017). DOI: 10.2305/IUCN.UK.20163.RLTS.T22685966A93094507.en.

Blackburn TM, Duncan RP 2001. Establishment patterns of exotic birds are constrained by non-random patterns in introduction. Journal of Biogeography 28:927-939. DOI: 10.1046/j.1365-2699.2001.00597.x.

Blackburn TM, Cassey P, Gaston KJ 2006. Variations on a theme: sources of heterogeneity in the form of the interspecific relationship between abundance and distribution. Journal of Animal Ecology 75:1426-1439. DOI: 10.1111/j.13652656.2006.01167.x.

Blackburn TM, Lockwood JL, Cassey P 2009. Avian invasions: The ecology and evolution of exotic birds. Oxford University Press. DOI: 10.1093/acprof:oso/9780199232543.001.0001.

Blackburn TM, Pysek P, Bacher S, Carlton JT, Duncan RP, Jarosik V, Wilson JRU, Richardson DM 2011. A proposed unified framework for biological invasions. Trends in Ecology \& Evolution 26:333-339. DOI: 10.1016/j.tree.2011.03.023.

Blanco G, Bravo C, Pacifico EC, Chamorro D, Speziale KL, Lambertucci SA, Hiraldo F, Tella JL 2016. Internal seed dispersal by parrots: an overview of a neglected mutualism. PeerJ 4:e1688. DOI: 10.7717/peerj.1688.

Blanco G, Hiraldo F, Tella JL 2017. Ecological functions of parrots: an integrative perspective from plant life cycle to ecosystem functioning. Emu - Austral Ornithology. DOI: 10.1080/01584197.2017.1387031. 
Blanco G, Hiraldo F, Rojas A, Dénes FV, Tella JL 2015. Parrots as key multilinkers in ecosystem structure and functioning. Ecology and Evolution 5:4141-4160. DOI: 10.1002/ece3.1663.

Blanco G, Tella JL, Potti J, Baz A 2001. Feather mites on birds: costs of parasitism or conditional outcomes? Journal of Avian Biology 32:271-274. DOI: 10.1111/j.09088857.2001.320310.x.

Bond J 1971. Sixteenth supplement to the Check-list of the Birds of the West Indies (1956). Philadelphia: Philadelphia Academy of Natural Sciences.

Briceno C, Surot D, Gonzalez-Acuna D, Javier Martinez F, Fredes F 2017. Parasitic survey on introduced monk parakeets (Myiopsitta monachus) in Santiago, Chile. Revista Brasileira De Parasitologia Veterinaria 26:129-135. DOI: 10.1590/S198429612017023.

Brightsmith D, Burgio KR, Hiller BJ, Block KE, Pyle P, Patten MA 2017. White-winged parakeet (Brotogeris versicolurus), vers. 3.0. In: Rodewald PG ed. The birds of North America. Cornell Lab of Ornithology. DOI: doi.org/10.2173/bna.whwpar.03.

Bueno ML, Pennington RT, Dexter KG, Kamino LHY, Pontara V, Neves DM, Ratter JA, Oliveira Filho AT 2017. Effects of Quaternary climatic fluctuations on the distribution of Neotropical savanna tree species. Ecography 40:403-414. DOI: 10.1111/ecog.01860.

Bush ER, Baker SE, MacDonald DW 2014. Global Trade in Exotic Pets 2006-2012. Conservation Biology 28:663-676. DOI: 10.1111/cobi.12240.

Butler CJ 2003. Population Biology of the Introduced Rose-ringed Parakeet Psittacula Krameri in the UK.

Camacho-Rodríguez M, Chabert-Llompart J, López-Flores M 1999. Guía para la identificación de las aves exóticas establecidas en Puerto Rico. San Juan: División de Recursos Terrestres, Departamento de Recursos Naturales y Ambientales de Puerto Rico.

Carrete M, Tella JL 2008. Wild-bird trade and exotic invasions: a new link of conservation concern? Frontiers in Ecology and the Environment 6:207-211. DOI: $10.1890 / 070075$.

Casagrande DG, Beissinger SR 1997. Evaluation of four methods for estimating parrot population size. Condor 99:445-457.

Cassey P 2001. Are there body size implications for the success of globally introduced land birds? Ecography 24:413-420.

Cassey P, Blackburn TM, Jones KE, Lockwood JL 2004a. Mistakes in the analysis of exotic species establishment: source pool designation and correlates of introduction success among parrots (Aves: Psittaciformes) of the world. Journal of Biogeography 31:277-284. DOI: 10.1046/j.0305-0270.2003.00979.x.

Cassey P, Blackburn TM, Russell GJ, Jones KE, Lockwood JL 2004b. Influences on the transport and establishment of exotic bird species: An analysis of the parrots (Psittaciformes) of the world. Global Change Biology 10:417-426. DOI: 10.1111/j.1529-8817.2003.00748.x.

Chapman CA, Chapman LJ, Lefebvre L 1989. Variability in Parrot Flock Size - Possible Functions of Communal Roosts. Condor 91:842-847.

Clark FD, Hume GM, Hayes ES 1988. An isolated case of avian pox in a military macaw (Ara militaris mexicana). Companion Animal Practice 2:34-35. 
Corlett RT 2013. Where are the Subtropics? Biotropica 45:273-275. DOI: 10.1111/btp. 12028 .

Dabert J, Mironov SV 1999. Origin and evolution of feather mites (Astigmata). Experimental and Applied Acarology 23:437-454. DOI: 10.1023/A:1006180705101.

Davis MA 2009. Invasion Biology. Oxford: Oxford University Press.

del Hoyo J, Collar NJ, Christie DA, Elliott A, Fishpool LDC 2014. HBW and BirdLife International Illustrated Checklist of the Birds of the World. Volume 1: Nonpasserines. Barcelona, Cambridge: Lynx Edicions - BirdLife International.

del Hoyo J, Elliott A, Sargatal J 1997. Handbook of the birds of the world. Volume 4, Sandgrouse to cuckoos. Barcelona: Lynx.

Departamento de Recursos Naturales y Ambientales de Puerto Rico 2003. Nuevo reglamento para regir la conservación y el manejo de vida silvestre, las especies exóticas y la caza en el Estado Libre Asociado de Puerto Rico.

Done LB, Tamura Y 2014. A presumptive case of Baylisascaris procyonis in a feral green-cheeked amazon parrot (Amazona Viridigenalis). Journal of Zoo and Wildlife Medicine 45:157-160. DOI: 10.1638/2012-0263R1.1.

Duncan RP, Blackburn TM, Cassey P 2006. Factors Affecting the Release, Establishment and Spread of Introduced Birds in New Zealand. In: Allen RB, Lee WG eds. Biological Invasions in New Zealand. Ecological Studies. Berlin/Heidelberg: Springer-Verlag, 137-154. DOI: 10.1007/3-540-30023-6_9.

Duque-Lazo J, van Gils H, Groen TA, Navarro-Cerrillo RM 2016. Transferability of species distribution models: The case of Phytophthora cinnamomi in Southwest Spain and Southwest Australia. Ecological Modelling 320:62-70. DOI: 10.1016/j.ecolmodel.2015.09.019.

Ehrlich PR 1986. Which animals will invade? In: Mooney HA, Drake JA eds. The ecology of biological invasions of North America and Hawaii. New York: SpringerVerlag, 79-95.

Falcón W, Ackerman JD, Daehler CC 2012. March of the green iguana: Non-native distribution and predicted geographic range of Iguana iguana in the Greater Caribbean Region. IRCF Reptiles and Amphibians 19:150-160.

Falcón W, Ackerman JD, Recart W, Daehler CC 2013. Biology and impacts of Pacific island invasive species. 10. Iguana iguana, the green iguana (Squamata: Iguanidae). Pacific Science 67:157-186. DOI: 10.2984/67.2.2.

Fick SE, Hijmans RJ 2017. WorldClim 2: new 1-km spatial resolution climate surfaces for global land areas. International Journal of Climatology 37:4302-4315. DOI: 10.1002/joc.5086.

Forshaw JM 1973. Parrots of the world. Melbourne: Lansdowne Press.

Forshaw JM 2010. Parrots of the World. Princeton: Princeton University Press.

Francisco MR, Lunardi VD, Galetti M 2002. Massive seed predation of Pseudobombax grandiflorum (Bombacaceae) by parakeets Brotogeris versicolurus (Psittacidae) in a forest fragment in Brazil. Biotropica 34:613-615. DOI: 10.1111/j.17447429.2002.tb00582.x.

Franklin J 2010. Mapping species distributions: Inference and prediction. Cambridge: Cambridge University Press. DOI: 10.1017/CBO9780511810602. 
Freeman EA, Moisen GG 2008. A comparison of the performance of threshold criteria for binary classification in terms of predicted prevalence and kappa. Ecological Modelling 217:48-58. DOI: 10.1016/j.ecolmodel.2008.05.015.

Freile J, Solano-Ugalde A, Salas J, Navarrete R 2012. Brotogeris versicolorus (Statius Müller, 1776) (Aves: Psittacidae): introduced established population in Ecuador. Check List 8(3):572. DOI: 10.15560/8.3.572.

Gaston KJ 2003. The Structure and Dynamics of Geographic Ranges. Oxford University Press, USA.

Gaston KJ, Jones AG, Hanel C, Chown SL 2003. Rates of species introduction to a remote oceanic island. Proceedings of the Royal Society B-Biological Sciences 270:1091-1098. DOI: 10.1098/rspb.2003.2332.

Gnam R, Burchsted A 1991. Population estimates for the Bahama parrot on Abaco Island, Bahamas. Journal of Field Ornithology 62:139-146.

González JA 2003. Análisis preliminar de los daños causados por las aves silvestres a la agricultura en la Amazonía oriental del Perú. In: Bogotá, 370-380.

Hamrick JL, Murawski DA, Nason JD 1993. The influence of seed dispersal mechanisms on the genetic-structure of tropical tree populations. Vegetatio 108:281-297. DOI: 10.1007/BF00052230.

Hernandes FA, Valim MP, Pedroso LGA 2016. New records of feather mites (Acari: Astigmata) from Pelecaniformes (Aves) in Brazil. Checklist 12:1-25. DOI: 10.15560/12.6.2000.

Hijmans RJ 2017. raster: Geographic data analysis and modeling.

Hijmans RJ, Cameron SE, Parra JL, Jones PG, Jarvis A 2005. Very high resolution interpolated climate surfaces for global land areas. International Journal of Climatology 25:1965-1978. DOI: 10.1002/joc.1276.

Howe F, Smallwood J 1982. Ecology of seed dispersal. Annual Review of Ecology and Systematics 13:201-228.

Janzen DH 1981. Ficus ovalis seed predation by an orange-hhinned parakeet (Brotogeris jugularis) in Costa Rica. Auk 98:841-844.

Jiménez-Valverde A, Lobo JM 2007. Threshold criteria for conversion of probability of species presence to either-or presence-absence. Acta Oecologica 31:361-369. DOI: 10.1016/j.actao.2007.02.001.

Juniper T, Parr M 1998. Parrots: a guide to the parrots of the world.

Kumschick S, Nentwig W 2010. Some alien birds have as severe an impact as the most effectual alien mammals in Europe. Biological Conservation 143:2757-2762. DOI: 10.1016/j.biocon.2010.07.023.

Lambert MS, Massei G, Yoder CA, Cowan DP 2010. An evaluation of Diazacon as a potential contraceptive in non-native rose-ringed parakeets. Journal of Wildlife Management 74:573-581. DOI: 10.2193/2008-531.

Le Louarn M, Couillens B, Deschamps-Cottin M, Clergeau P 2016. Interference competition between an invasive parakeet and native bird species at feeding sites. Journal of Ethology 34:291-298. DOI: 10.1007/s10164-016-0474-8.

Lin Neo M 2012. A review of three alien parrots in Singapore. Nature in Singapore 5:241-248. 
Liu C, Berry PM, Dawson TP, Pearson RG 2005. Selecting thresholds of occurrence in the prediction of species distributions. Ecography 28:385-393. DOI: 10.1111/j.09067590.2005.03957.x.

Lockwood JL 1999. Using taxonomy to predict success among introduced avifauna: Relative importance of transport and establishment. Conservation Biology 13:560567. DOI: 10.1046/j.1523-1739.1999.98155.x.

Lockwood JL, Brooks TM, McKinney ML 2000. Taxonomic homogenization of the global avifauna. Animal Conservation 3:27-35.

Lockwood JL, Hoopes MF, Marchetti MP 2013. Invasion ecology. John Wiley \& Sons.

Magnino S, Conzo G, Fioretti A, Menna LF, Rampin T, Sironi G, Fabbi M, Kaleta EF 1996. An outbreak of Pacheco's parrot disease in psittacine birds recently imported to Campania, Italy: Isolation of Psittacid Herpesvirus 2. Journal of Veterinary Medicine, Series B 43:631-637. DOI: 10.1111/j.1439-0450.1996.tb00362.x.

Manel S, Williams HC, Ormerod SJ 2001. Evaluating presence-absence models in ecology: the need to account for prevalence. Journal of Applied Ecology 38:921-931. DOI: 10.1046/j.1365-2664.2001.00647.x.

Martens J, Hoppe D, Woog F 2013. Diet and feeding behaviour of naturalised amazon parrots in a European city. Ardea 101:71-76. DOI: 10.5253/078.101.0111.

Mase M, Imada T, Sanada Y, Etoh M, Sanada N, Tsukamoto K, Kawaoka Y, Yamaguchi S 2001. Imported parakeets harbor H9N2 influenza A viruses that are genetically closely related to those transmitted to humans in Hong Kong. Journal of Virology 75:3490-3494. DOI: 10.1128/JVI.75.7.3490-3494.2001.

Menchetti M, Mori E 2014. Worldwide impact of alien parrots (Aves Psittaciformes) on native biodiversity and environment: a review. Ethology Ecology and Evolution 26:172-194. DOI: 10.1080/03949370.2014.905981.

Mooney HA 2005. Invasive Alien Species. Island Press.

Mori E, Ancillotto L, Menchetti M, Strubbe D 2017. "The early bird catches the nest": possible competition between scops owls and ring-necked parakeets. Animal Conservation 20:463-470. DOI: 10.1111/acv.12334.

Mori E, Di Febbraro M, Foresta M, Melis P, Romanazzi E, Notari A, Boggiano F 2013. Assessment of the current distribution of free-living parrots and parakeets (Aves: Psittaciformes) in Italy: a synthesis of published data and new records. Italian Journal of Zoology 80:158-167. DOI: 10.1080/11250003.2012.738713.

Moulton MP, Pimm SL 1986. Species introductions to Hawaii. In: Mooney HA, Drake JA eds. The ecology of biological invasions of North America and Hawaii. New York, 231-249.

Nathan R, Muller-Landau HC 2000. Spatial patterns of seed dispersal, their determinants and consequences for recruitment. Trends in Ecology \& Evolution 15:278-285. DOI: 10.1016/S0169-5347(00)01874-7.

Newson SE, Johnston A, Parrott D, Leech DI 2011. Evaluating the population-level impact of an invasive species, ting-necked parakeet Psittacula krameri, on native avifauna. Ibis 153:509-516. DOI: 10.1111/j.1474-919X.2011.01121.x.

Norconk MA, Grafton BW, Conklin Brittain NL 1998. Seed dispersal by neotropical seed predators. American Journal of Primatology 45:103-126. DOI: 10.1002/(SICI)10982345(1998)45:1<103::AID-AJP8>3.0.CO;2-\#.

Oberle MW 2000. Puerto Rico's Birds in Photographs. San Juan: Editorial Humanitas. 
Olson SL 2015. History, morphology, and fossil record of the extinct Puerto Rican parakeet Psittacara maugei Souance. Wilson Journal of Ornithology 127:1-12. DOI: 10.1676/14-020.1.

Orchan Y, Chiron F, Shwartz A, Kark S 2012. The complex interaction network among multiple invasive bird species in a cavity-nesting community. Biological Invasions 15:429-445. DOI: 10.1007/s10530-012-0298-6.

Orosz SE, Chengappa MM, Oyster RA, Morris PJ, Trock S, Altekruse S 1992. Salmonella enteritidis infection in two species of psittaciformes. Avian Diseases 36:766-769.

Pérez-Rivera RA 1985. Nuevos informes y notas adicionales sobre las aves exóticas que han alcanzado el estado silvestre en Puerto Rico. Science-Ciencia 12:46-48.

Pérez-Rivera RA, Vélez-Miranda M 1980. La proliferación de Psittaciformes en Puerto Rico y el problema que éstos representan. In: San Juan, 115-127. DOI: 10.2307/30243118.

Pérez-Rivera RA, Colón Méndez G, Ríos Estrella W, de Jesús Suárez WL 1985. Aspectos de la ecología del periquito de ala amarilla (Brotogeris versicolurus) en Puerto Rico. Science-Ciencia 12:1-5.

Phillips SJ, Anderson RP, Schapire RE 2006. Maximum entropy modeling of species geographic distributions. Ecological Modelling 190:231-259. DOI: 10.1016/j.ecolmodel.2005.03.026.

Phillips SJ, Dudík M, Schapire RE 2017. Maxent software for modeling species niches and distributions.

Pimm SL 1989. Theories of predicting success and impact of introduced species. In: Drake JA, di Castri F, Groves RH, Kruger FJ, Rejmanek M, Williamson M eds. Biological invasions. John Wiley \& Sons Incorporated, 351-367.

Pimm SL, Jones HL, Diamond J 1988. On the Risk of Extinction. American Naturalist 132:757-785. DOI: $10.1086 / 284889$.

Pithon JA, Dytham C 1999. Census of the British ring-necked parakeet Psittacula krameri population by simultaneous counts of roosts. Bird Study 46:112-115. DOI: $10.1080 / 00063659909461121$.

QGIS Development Team 2017. QGIS Geographic Information System.

R Core Team 2017. R: A language and environment for statistical computing.

Raffaele HA 1989. A Guide to the Birds of Puerto Rico and the Virgin Islands.

Robinson JM 2001. The dynamics of avicultural markets. Environmental Conservation 28:76-85. DOI: 10.1017/S0376892901000078.

Runde DE, Pitt WC, Foster JT 2007. Population ecology and some potential impacts of emerging populations of exotic parrots. In: 338-360.

Sa RCC, Cunningham AA, Dagleish MP, Wheelhouse N, Pocknell A, Borel N, Peck HL, Lawson B 2014. Psittacine beak and feather disease in a free-living ring-necked parakeet (Psittacula krameri) in Great Britain. European Journal of Wildlife Research 60:395-398. DOI: 10.1007/s10344-013-0792-x.

Saikku M 1990. The extinction of the Carolina parakeet. Environmental History Review 14:1-18. DOI: 10.2307/3984724?ref=searchgateway:740719859c1e4c91076887de58d83707.

Sakai AK, Allendorf FW, Holt JS, Lodge DM, Molofsky J, With KA, Baughman S, Cabin RJ, Cohen JE, Ellstrand NC, McCauley DE, O'Neil P, Parker IM, Thompson 
JN, Weller SG 2001. The population biology of invasive species. Annual Review of Ecology and Systematics 32:305-332. DOI:

10.1146/annurev.ecolsys.32.081501.114037.

Sanders NJ, Gotelli NJ, Heller NE, Gordon DM 2003. Community disassembly by an invasive species. Proceedings of the National Academy of Sciences 100:2474-2477. DOI: $10.1073 /$ pnas.0437913100.

Schroads CV 1974. Studies in a population of the canary-winged parakeet, Brotogeris versicolurus (PLS Müller) in Dade County, Florida (Aves: Psittacidae). University of Miami.

Seebens H, Blackburn TM, Dyer EE, Genovesi P, Hulme PE, Jeschke JM, Pagad S, Pysek P, Winter M, Arianoutsou M, Bacher S, Blasius B, Brundu G, Capinha C, Celesti-Grapow L, Dawson W, Dullinger S, Fuentes N, Jaeger H, Kartesz J, Kenis M, Kreft H, Kuehn I, Lenzner B, Liebhold A, Mosena A, Moser D, Nishino M, Pearman D, Pergl J, Rabitsch W, Rojas-Sandoval J, Roques A, Rorke S, Rossinelli S, Roy HE, Scalera R, Schindler S, Stajerova K, Tokarska-Guzik B, van Kleunen M, Walker K, Weigelt P, Yamanaka T, Essl F 2017. No saturation in the accumulation of alien species worldwide. Nature Communications 8. DOI: 10.1038/ncomms14435.

Smith KF, Behrens M, Schloegel LM, Marano N, Burgiel S, Daszak P 2009. Reducing the risks of the wildlife trade. Science 324:594-595. DOI: $10.1126 /$ science. 1174460.

Snyder NFR, McGowan P, Gilardi J, Grajal A (eds.) 2000. Parrots: Status survey and conservation action plan 2000-2004. Cambridge: IUCN.

Snyder NFR, Wieley W, Kepler CB 2007. The parrots of Luquillo: Natural history and conservation of the Puerto Rican parrot. Camarillo: Western Foundation of Vertebrate Zoology. DOI: 10.1086/283697.

Strubbe D, Matthysen E 2009a. Experimental evidence for nest-site competition between invasive ring-necked parakeets (Psittacula krameri) and native nuthatches (Sitta europaea). Biological Conservation 142:1588-1594. DOI: 10.1016/j.biocon.2009.02.026.

Strubbe D, Matthysen E 2009b. Establishment success of invasive ring-necked and monk parakeets in Europe. Journal of Biogeography 36:2264-2278. DOI: 10.1111/j.13652699.2009.02177.x.

Swets JA 1988. Measuring the accuracy of diagnostic systems. Science 240:1285-1293. DOI: $10.1126 /$ science.3287615.

Symes CT 2014. Founder populations and the current status of exotic parrots in South Africa. Ostrich 85:235-244. DOI: 10.2989/00306525.2014.921866.

Thomsen JB, Edwards SR, Mulliken TA, Network IT 1992. Perceptions, conservation, and management of wild birds in trade. Traffic International.

Tossas AG, Colón YM, Sanders I 2012. Seasonal changes in roost counts of the nonnative white-winged parakeet (Brotogeris versicolurus) in San Germán, Puerto Rico. Journal of Caribbean Ornithology 25:1-6.

Veit RR 1997. Long-distance dispersal and population growth of the yellow-headed blackbird Xanthocephalus xanthocephalus. Ardea 85:135-143.

Veit RR 2000. Vagrants as the expanding fringe of a growing population. Auk 117:242246.

Wickham H 2011. The split-apply-combine strategy for data analysis. Journal of Statistical Software 40:1-29. DOI: 10.18637/jss.v040.i01. 
Wickham H 2016. ggplot2: Elegant graphics for data analysis. Cham: Springer. DOI: 10.1007/978-3-319-24277-4.

Yoder CA, Avery ML, Keacher KL, Tillman EA 2007. Use of DiazaCon ${ }^{\mathrm{TM}}$ as a reproductive inhibitor for monk parakeets (Myiopsitta monachus). Wildlife Research 34:8-13. DOI: 10.1071/WR06069.

Zeileis A, Grothendieck G 2005. zoo: S3 infrastructure for regular and irregular time series. Journal of Statistical Software 14:1-27. DOI: 10.18637/jss.v014.i06. 


\section{TABLES}

Table 1: Introduced Psittaciformes reported in Puerto Rico, their native range, invasiveness and their current status on the island.

\begin{tabular}{|c|c|c|c|c|c|c|}
\hline Species & Common name & Red List & Native range & Invasiveness & Status & Pet trade \\
\hline Agapornis fischeri & Fischer's lovebird & NT & Tanzania & D1-D2 & $\mathrm{C} 0-\mathrm{C} 2$ & $\mathrm{Y}$ \\
\hline Agapornis personatus & Masked lovebird & $\mathrm{LC}$ & Tanzania & D1-D2 & $\mathrm{C} 0-\mathrm{C} 2$ & $\mathrm{Y}$ \\
\hline Agapornis roseicollis & Peach-faced lovebirds & $\mathrm{LC}$ & Southern Africa & $\mathrm{C} 0-\mathrm{C} 2$ & $\mathrm{C} 0-\mathrm{C} 2$ & $\mathrm{Y}$ \\
\hline Amazona aestiva & Blue-fronted amazon & $\mathrm{LC}$ & South America & $\mathrm{C} 0-\mathrm{C} 2$ & $\mathrm{C} 0-\mathrm{C} 2$ & $\mathrm{Y}$ \\
\hline Amazona albifrons & White-fronted amazon & $\mathrm{LC}$ & Central America & $\mathrm{C} 0-\mathrm{C} 2$ & $\mathrm{C} 3$ & $\mathrm{Y}$ \\
\hline Amazona amazonica & Orange-winged amazon & $\mathrm{LC}$ & South America & D1-D2 & $\mathrm{E}$ & $\mathrm{Y}$ \\
\hline Amazona auropalliata & Yellow-naped amazon & VU & Central America & $\mathrm{C} 0-\mathrm{C} 2$ & $\mathrm{~B} 2$ & $\mathrm{Y}$ \\
\hline Amazona leucocephala & Cuban amazon & NT & Western Caribbean & B2 & $\mathrm{C} 0-\mathrm{C} 2$ & $\mathrm{U}$ \\
\hline Amazona ochrocephala & Yellow-crowned amazon & $\mathrm{LC}$ & South America & D1-D2 & $\mathrm{C} 0-\mathrm{C} 3$ & $\mathrm{U}$ \\
\hline Amazona oratrix & Yellow-headed amazon & $\mathrm{EN}$ & Central America & $\mathrm{C} 0-\mathrm{C} 2$ & $\mathrm{C} 0-\mathrm{C} 3$ & $\mathrm{Y}$ \\
\hline Amazona ventralis & Hispaniolan amazon & VU & Hispaniola & $\mathrm{C} 0-\mathrm{C} 2$ & $\mathrm{C} 0-\mathrm{C} 3$ & $\mathrm{U}$ \\
\hline Amazona viridigenalis & Greencheeked amazon & $\mathrm{EN}$ & Mexico & $\mathrm{C} 0-\mathrm{C} 2$ & $\mathrm{C} 3$ & $\mathrm{Y}$ \\
\hline Anodorhynchus hyacinthinus & Hyacinth macaw & VU & South America & $\mathrm{B} 2$ & $\mathrm{~B} 2$ & $\mathrm{Y}$ \\
\hline Ara ararauna & Blue-and-yellow macaw & $\mathrm{LC}$ & South America & $\mathrm{C} 0-\mathrm{C} 2$ & $\mathrm{E}$ & $\mathrm{Y}$ \\
\hline Ara chloropterus & Red-and-green macaw & $\mathrm{LC}$ & South America & B2 & $\mathrm{C} 0-\mathrm{C} 2$ & $\mathrm{Y}$ \\
\hline
\end{tabular}




\begin{tabular}{|c|c|c|c|c|c|}
\hline Ara macao & Scarlet macaw & $\mathrm{LC}$ & C.-S. America & B2 & $\mathrm{C} 0-\mathrm{C} 3$ \\
\hline Ara militaris & Military macaw & VU & South America & $\mathrm{C} 0-\mathrm{C} 2$ & $\mathrm{C} 0-\mathrm{C} 2$ \\
\hline Aratinga (Nandayus) nenday & Nanday conure & $\mathrm{LC}$ & Northern S. America & D1-D2 & $\mathrm{C} 0-\mathrm{C} 2$ \\
\hline Aratinga jandaya & Jandaya conure & $\mathrm{LC}$ & Brazil & B2 & B2 \\
\hline Aratinga solstitialis & Sun conure & EN & Brazil, Guyana & $\mathrm{C} 0-\mathrm{C} 2$ & B2 \\
\hline Brotogeris versicolurus & White-winged parakeet & $\mathrm{LC}$ & South America & $\mathrm{E}$ & $\mathrm{E}$ \\
\hline Cacatua alba & White-crested cockatoo & EN & Indonesia & $\mathrm{C} 0-\mathrm{C} 2$ & $\mathrm{C} 0-\mathrm{C} 2$ \\
\hline Cacatua galerita & Sulfur-crested cockatoo & $\mathrm{LC}$ & Australasia, Indonesia & D1-D2 & $\mathrm{C} 0-\mathrm{C} 2$ \\
\hline Cacatua goffiniana & Goffin's corella & NT & Indonesia & D1-D2 & $\mathrm{C} 0-\mathrm{C} 2$ \\
\hline Cacatua moluccensis & Salmon-crested cockatoo & VU & Indonesia & B2 & $\mathrm{C} 0-\mathrm{C} 2$ \\
\hline Cacatua sulfurea & Yellow-crested cockatoo & $\mathrm{CR}$ & Timor-Leste, Indonesia & B2 & B2 \\
\hline Eupsittula (Aratinga) canicularis & Orange-fronted conure & $\mathrm{LC}$ & Central America & B2 & $\mathrm{E}$ \\
\hline Eupsittula (Aratinga) pertinax & Brown-throated conure & $\mathrm{LC}$ & Aruba, C.-S. America & $\mathrm{C} 0-\mathrm{C} 2$ & $\mathrm{C} 0-\mathrm{C} 2$ \\
\hline Forpus passerinus & Green-rumped parrolet & $\mathrm{LC}$ & Northern S. America & D1-D2 & B2 \\
\hline Melopsittacus undulatus & Budgerigar & $\mathrm{LC}$ & Australia & $\mathrm{C} 0-\mathrm{C} 2$ & $\mathrm{C} 0-\mathrm{C} 2$ \\
\hline Myiopsitta monachus & Monk parakeet & $\mathrm{LC}$ & South America & E & $\mathrm{E}$ \\
\hline Nymphicus hollandicus & Cockatiel & $\mathrm{LC}$ & Australia & $\mathrm{C} 0-\mathrm{C} 2$ & $\mathrm{C} 0-\mathrm{C} 2$ \\
\hline Poicephalus senegalus & Senegal & $\mathrm{LC}$ & Africa & B2 & $\mathrm{C} 0-\mathrm{C} 2$ \\
\hline
\end{tabular}


Psephotus haematonotus

Psittacara (Aratinga) chloropterus

Psittacara (Aratinga) erythrogenys

Psittacara mitratus

Psittacula krameri

Psittacus erithacus

Psittacus timneh

Pyrrhura hoffmanni

Pyrrhura molinae

Pyrrhura perlata

Pyrrhura roseifrons

Thectocercus acuticaudatus

Trichoglossus haematodus
Hispaniolan conure

Red-masked conure

Mitred conure

Roseringed parakeet

African grey parrot

Timneh parrot

Sulphur-winged parakeet

Green-cheeked conure

Crimson-bellied conure

Rose-fronted parakeet

Blue-crowned parakeet

Rainbow lorikeet
Red-rumped parrot
Australia

Hispaniola

NT Ecuador, Peru

LC South America

LC Africa and Asia

EN

Africa

EN West Africa

LC

South America

VU

South America

LC South America

NA South America

LC Australasia, Indonesia
LC Central America
B2

$\mathrm{C} 0-\mathrm{C} 2$

D1-D2

B2

E

$\mathrm{C} 0-\mathrm{C} 2$

B2

B2

B2

B2

B2

$\mathrm{C} 0-\mathrm{C} 2$

$\mathrm{C} 0-\mathrm{C} 2$
B2

Y

$\mathrm{C} 0-\mathrm{C} 3 \quad \mathrm{U}$

D2 Y

$\mathrm{C} 0-\mathrm{C} 2 \quad \mathrm{Y}$

$\mathrm{C} 0-\mathrm{C} 2 \quad \mathrm{Y}$

B2 $\quad \mathrm{Y}$

B2 $\mathrm{Y}$

C0-C2 Y

$\mathrm{C} 0-\mathrm{C} 2 \quad \mathrm{Y}$

B2 $\quad \mathrm{Y}$

$\mathrm{C} 0-\mathrm{C} 2 \quad \mathrm{U}$

$\mathrm{C} 0-\mathrm{C} 2 \quad \mathrm{U}$

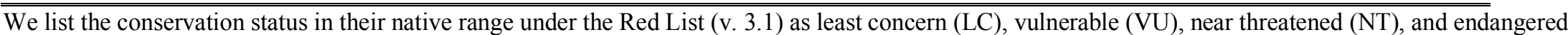
(EN). 'Invasiveness' represent the invasion stage reported outside of Puerto Rico (invasiveness potential) and 'Status' represent the invasion stage at which a species is at the moment in Puerto Rico, according to the categorization scheme by Blackburn et al. (2011; see below for the definitions). 'Pet trade' indicates if the species is known to be currently sold as pet $(\mathrm{Y})$ or unknown $(\mathrm{U})$ in Puerto Rico. Basis of records are from observations by the authors during the surveys, historical records in the literature (prior to 2000), geo-referenced records from online databases, and/or citizen-science records from local birding groups (see electronic supplementary material S1 for the origin of the data). Definitions of invasiveness and status are as follow:

$\mathbf{A}=$ Not transported beyond limits of native range

B1 = Individuals transported beyond limits of native range, and in captivity or quarantine (i.e. individuals provided with conditions suitable for them, but explicit measures of containment are in place)

$\mathbf{B 2}=$ Individuals transported beyond limits of native range, and in cultivation (i.e. individuals provided with conditions suitable for them but explicit measures to prevent dispersal are limited at best) 
B3 = Individuals transported beyond limits of native range, and directly released into novel environment

$\mathbf{C O}=$ Individuals released into the wild (i.e. outside of captivity or cultivation) in location where introduced, but incapable of surviving for a significant period

C1 = Individuals surviving in the wild (i.e. outside of captivity or cultivation) in location where introduced, no reproduction

C2 = Individuals surviving in the wild in location where introduced, reproduction occurring, but population not self-sustaining

C3 = Individuals surviving in the wild in location where introduced, reproduction occurring, and population self-sustaining

D1 = Self-sustaining population in the wild, with individuals surviving a significant distance from the original point of introduction

D2 = Self-sustaining population in the wild, with individuals surviving and reproducing a significant distance from the original point of introduction

$\mathbf{E}=$ Fully invasive species, with individuals dispersing, surviving and reproducing at multiple sites across a greater or lesser spectrum of habitats and extent of occurrence 
Table 2: Occurrence locations and MaxEnt summary statistics for predicting the distribution of four species of Psittaciformes in Puerto Rico.

\begin{tabular}{lcccc}
\hline \hline \multicolumn{1}{c}{ Species } & Occ. loc. & Training AUC & Test AUC & MS+ST \\
\hline Brotogeris versicolurus & $1,119(557)$ & $0.91( \pm 0.001)$ & $0.92( \pm 0.006)$ & $0.27( \pm 0.024)$ \\
Myopsitta monachus & $15,985(707)$ & $0.82( \pm 0.001)$ & $0.82( \pm 0.004)$ & $0.30( \pm 0.031)$ \\
Psittacara erythrogenys & $1,392(42)$ & $0.94( \pm 0.002)$ & $0.94( \pm 0.003)$ & $0.20( \pm 0.036)$ \\
Eupsittula canicularis & $3,707(55)$ & $0.84( \pm 0.001)$ & $0.84( \pm 0.005)$ & $0.27( \pm 0.014)$
\end{tabular}

Total occurrence locations used for the model (Occ. loc.), and the subset of occurrence locations for Puerto Rico given in parentheses. Model performance for predicting the distribution of four species of Psittaciformes in Puerto Rico given by the training ( $80 \%$ occurrence points) and test (20\% occurrence points) Area Under the ROC Curve (AUC), and the Maximum training Sensitivity plus Specificity presence-absence threshold $(\mathrm{MS}+\mathrm{ST})$. Values given are the mean $( \pm \mathrm{SD})$ based on ten replicates. 
Table 3: Plant resources used by the white-winged parakeet, Brotogeris versicolurus for food and nesting in Puerto Rico. Information based on observations made during the study period, with additional information from Pérez-Rivera et al. (1985).

\begin{tabular}{|c|c|c|c|}
\hline Species & Common name & Status & Resou \\
\hline & & & Food resources \\
\hline Albizia procera & White siris & Invasive & sap \\
\hline Annona muricata & Soursop & Exotic & fruits \\
\hline Artocarpus heterophyllus & Jackfruit & Exotic & flowers \\
\hline Bucida buceras & Bullet tree & Native & flowers, seeds \\
\hline Callistemon citrinus & Lemon bottlebrush & Exotic & flowers, nectar \\
\hline Carica papaya & Papaya & Exotic & fruits \\
\hline Cassia javanica & Pink shower tree & Exotic & flowers \\
\hline Cassuarina equisetifolia & Australian 'pine' & Invasive & seeds \\
\hline Cecropia peltata & Trumpet tree & Native & fruits \\
\hline Ceiba pentandra & Kapok & Native & flowers \\
\hline Citrus paradisi & Grapefruit & Exotic & fruits \\
\hline Clusia rosea & Autograph tree & Native & seeds \\
\hline Cocos nucifera & Coconut palm tree & Exotic & flowers, nectar? \\
\hline Cordia sebestena & Scarlet cordia & Native & flowers, nectar? \\
\hline Delonix regia & Royal poinciana & Exotic & flowers \\
\hline Erythrina poeppigiana & Coral tree & Exotic & shoots \\
\hline Ficus americana & West Indian fig & Native & fruits \\
\hline Ficus citrifolia & Shortleaf fig & Native & fruits \\
\hline Inga vera & Guaba & Native & seeds \\
\hline Malpighia emarginata & Barbados cherry & Native & fruits \\
\hline Mangifera indica & Mango & Exotic & flowers, fruits \\
\hline Musa acuminata & Banana & Exotic & fruits \\
\hline Musa paradisiaca & Plantain & Exotic & fruits \\
\hline Ochroma pyramidale & Balsa & Exotic & seeds \\
\hline
\end{tabular}




$\begin{array}{llll}\begin{array}{l}\text { Pithecellobium dulce } \\ \text { Psidium guajava }\end{array} & \text { Manilla tamarind } & \text { Exotic } & \text { flowers, seeds } \\ \text { Pterocarpus officinalis } & \text { Dragonsblood tree } & \text { Exotic } & \text { fruits } \\ \text { Roystonea borinquena } & \text { Royal palm } & \text { flowers } \\ \text { Spathodea campanulata } & \text { African tulip tree } & \text { Native } & \text { fruits } \\ \text { Spondias mombin } & \text { Yellow mombin } & \text { Exotic } & \text { fruits } \\ \text { Spondias purpurea } & \text { Red mombin } & \text { Exotic } & \text { fruits } \\ \text { Sterculia apetala } & \text { Panama tree } & \text { Exotic } & \text { seeds } \\ \text { Swietenia mahogani } & \text { West Indian mahogany } & \text { Exotic } & \text { seeds } \\ \text { Syzygium jambos } & \text { Water apple } & \text { Exotic } & \text { fruits } \\ \text { Tabebuia heterophylla } & \text { Pink trumpet tree } & \text { Native } & \text { flowers, seeds } \\ \text { Terminalia catappa } & \text { Indian almond } & \text { Exotic } & \text { fruits } \\ \text { Zanthoxylum martinicense } & \text { Prickly ash } & \text { Exotic } & \text { shoots }\end{array}$

\section{$\underline{\text { Roosting resources }}$}

$\begin{array}{llll}\text { Callophyllum antillanum } & \text { Antilles calophyllum } & \text { Native } & - \\ \text { Roystonea borinquena } & \text { Royal palm } & \text { Native } & - \\ \text { Eucalyptus deglupta } & \text { Rainbow eucalyptus } & \text { Exotic } & - \\ \text { Swietenia mahogani } & \text { West Indian mahogani } & \text { Exotic } & -\end{array}$

\section{Nesting resources}

$\begin{array}{llll}\text { Albizia procera } & \text { White siris } & \text { Exotic } & \text { termite mounds } \\ \text { Artocarpus heterophyllus } & \text { Jackfruit } & \text { Exotic } & \text { termite mounds } \\ \text { Cordia sulcata } & \text { White manjack } & \text { Native } & \text { termite mounds } \\ \text { Delonix regia } & \text { Royal poinciana } & \text { Exotic } & \text { termite mounds } \\ \text { Dendropanax arboreus } & \text { Angelica tree } & \text { Native } & \text { termite mounds } \\ \text { Ficus citrifolia } & \text { Shortleaf fig } & \text { Native } & \text { termite mounds } \\ \text { Mangifera indica } & \text { Mango } & \text { Exotic } & \text { termite mounds } \\ \text { Pithecellobium saman } & \text { Albizia saman } & \text { Exotic } & \text { termite mounds } \\ \text { Schefflera morototoni } & \text { Yagrumo macho } & \text { Native } & \text { termite mounds }\end{array}$



not certified by peer review) is the author/funder. All rights reserved. No reuse allowed without permission.

$\begin{array}{llll}\text { Spondeas mombin } & \text { Yellow mombin } & \text { Exotic } & \text { termite mounds } \\ \text { Swietenia macrophylla } & \text { Honduran mahogani } & \text { Exotic } & \text { termite mounds } \\ \text { Swietenia mahogani } & \text { West Indian mahogani } & \text { Exotic } & \text { termite mounds } \\ \text { Tamarindus indica } & \text { Tamarind } & \text { Exotic } & \text { termite mounds } \\ \text { Terminalia catappa } & \text { Indian almond } & \text { Exotic } & \text { termite mounds } \\ \text { Zanthoxylum martinicense } & \text { Prickly ash } & \text { Native } & \text { termite mounds }\end{array}$


Table 4: Population estimates and growth rates of the white-winged parakeet (Brotogeris versicolurus) at two sites in Puerto Rico. Counts were performed during the non-breeding season $\left(\mathrm{N}_{\mathrm{nb}}\right)$

\begin{tabular}{c|cc|cc}
\hline \hline Year & \multicolumn{2}{|c|}{ San Patricio } & \multicolumn{2}{|c}{ San Germán } \\
& $\mathbf{N}_{\mathbf{n b}}$ & $\lambda$ & $\mathbf{N}_{\mathbf{n b}}$ & $\lambda$ \\
\hline 1975 & - & - & $200^{*}$ & - \\
1981 & $360^{*}$ & - & $800^{\#}$ & 1.07 \\
1995 & - & - & $1,335^{\dagger}$ & 1.05 \\
2005 & - & - & 1,503 & 1.13 \\
2007 & 1,299 & 1.05 & 1,779 & 1.18 \\
2008 & 2,301 & 1.77 & 2,406 & 1.35 \\
2009 & 3,128 & 1.36 & 3,010 & 1.25 \\
2010 & 2,531 & 0.81 &
\end{tabular}

Data from based on this study, and on historical records (Pérez-Rivera et al. 1985*; Camacho-Rodríguez et al. 1999\#; unknown time of the year recorded for both; Tossas et al. $2012^{\dagger}$, recorded in October). We define the population size as ' $N N_{n b}$ ', and the population growth rate as ' $\lambda$ '. The population size was estimated during the non-breeding season. The population grows if $\lambda>1$, decreases if $\lambda<1$ and is stationary if $\lambda=0$. The population decline in San Patricio from 2009-2010 is probably a result of emigration (see main text). 
Table 4: Breeding proportion of the population based on the 2010 breeding $\left(N_{b}\right)$ and non-breeding season counts at the roosting site, the estimated number of pairs, expected chick production and the estimated number of fledglings.

\begin{tabular}{cccccc}
\hline \hline Population & $\mathbf{N}_{\mathbf{b}}$ & Breeding prop. & No. of pairs & Chicks & Fledglings \\
\hline San Patricio & 1,879 & 0.40 & 625 & 1,250 & 604 \\
San Germán & 1,382 & 0.42 & 512 & 1,024 & - \\
\hline \hline
\end{tabular}

We assumed a mean of two chicks produced per pair. It was not possible to estimate the number of fledglings for 2010 in San Germán because there was a population decrease likely due to emigration. 


\section{FIGURES}
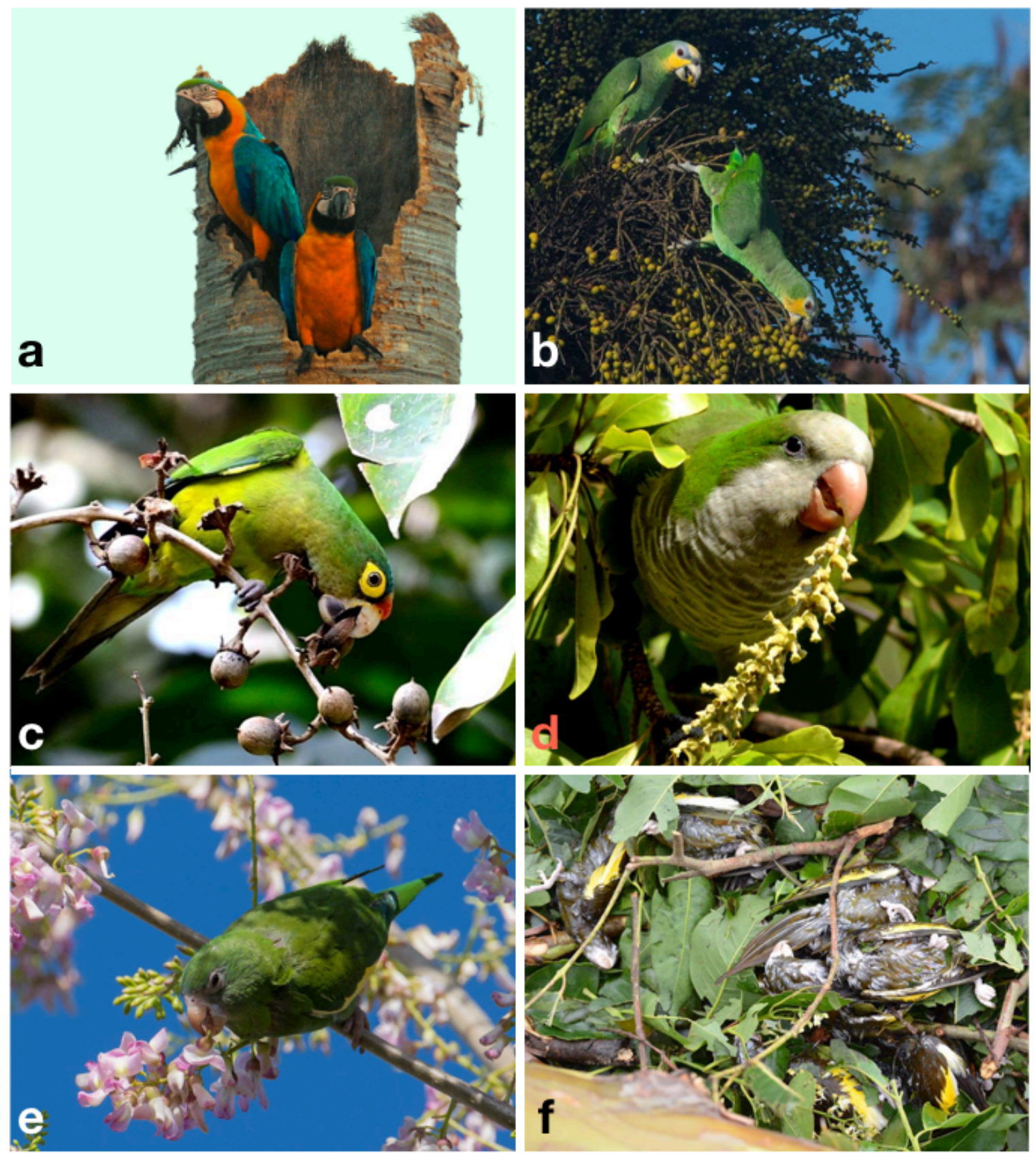

Figure 1: Some of the species of Psittaciformes that occur in the wild in Puerto Rico, and Hurricane Maria-related mortality. A pair of blue-and-yellow macaws (Ara ararauna) in their nest on Roystonea borinquena (Aracaceae; a), an orange-winged amazon (Amazona amazonica) eating palm fruits (Aracaceae; b), an orange-fronted parakeet (Eupsittula canicularis) foraging on seed of Lagerstroemia speciosa (Lythraceae; c), a monk parakeet (Myiopsitta monachus) eating the flower buds of Bucida buceras (Combretaceae; d), a white-winged parakeet (Brotogeris versicolurus) eating flower buds (Fabaceae; e), and six out of dozens of white-winged parakeets that died during 

not certified by peer review) is the author/funder. All rights reserved. No reuse allowed without permission.

Hurricane María in 2017 (f). Photo credits: Yoly Pereira (a), Julio Salgado (b, e), Pedro Santana (c), Sonia Longoria (d), Dinath Figueroa (f). 


\section{Increasing}

Monk parakeet

(Myopsitta monachus)

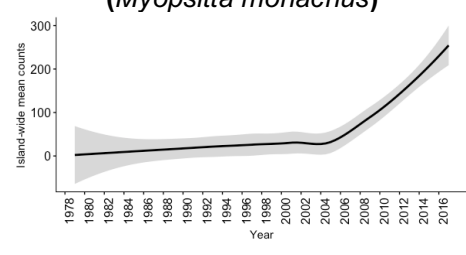

Red-masked conure (Psittacara (Aratinga) erythrogenys)
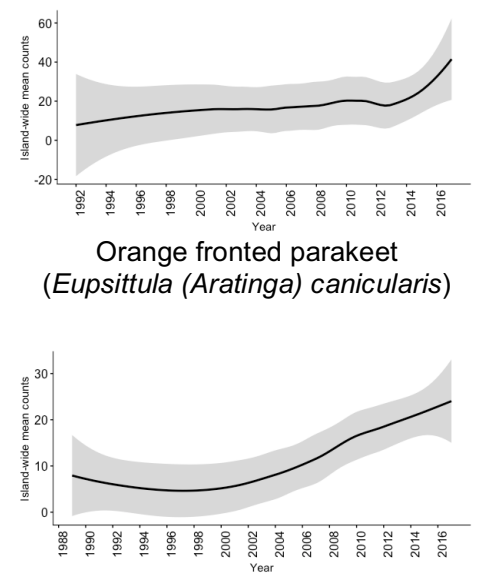

\section{Stable}

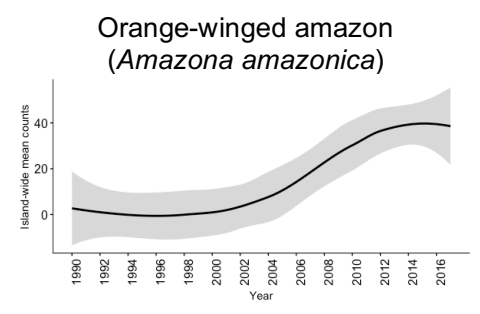

Blue-and-yellow macaw (Ara aranaura)
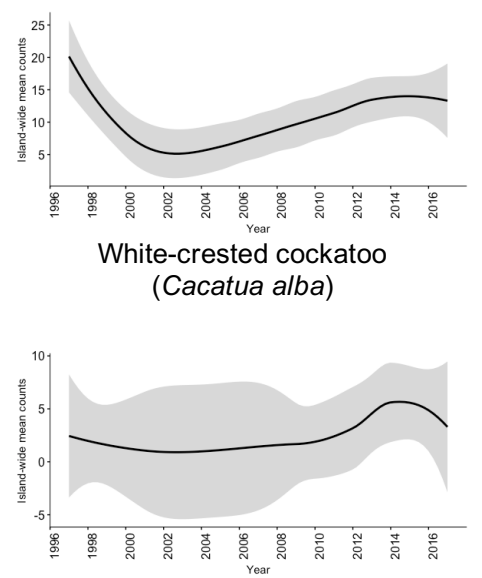

\section{Decreasing}

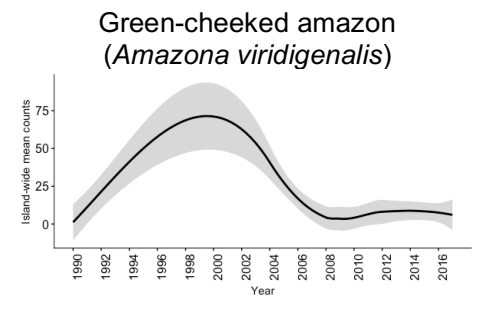

White-fronted amazon

(Amazona albifrons)
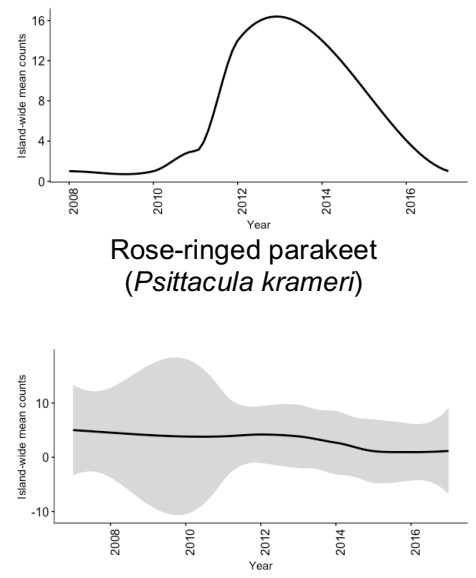

Figure 2: Sighting trends of different species of Psittaciformes in Puerto Rico showing population increase, stable populations and population decrease. Island-wide sighting trends were calculated as the sum of the mean number of birds counted per year/municipality (data from Ebird). Grey shading indicates the $95 \% \mathrm{CI}$ based on the local weighted scatterplot smoothing (loess). 


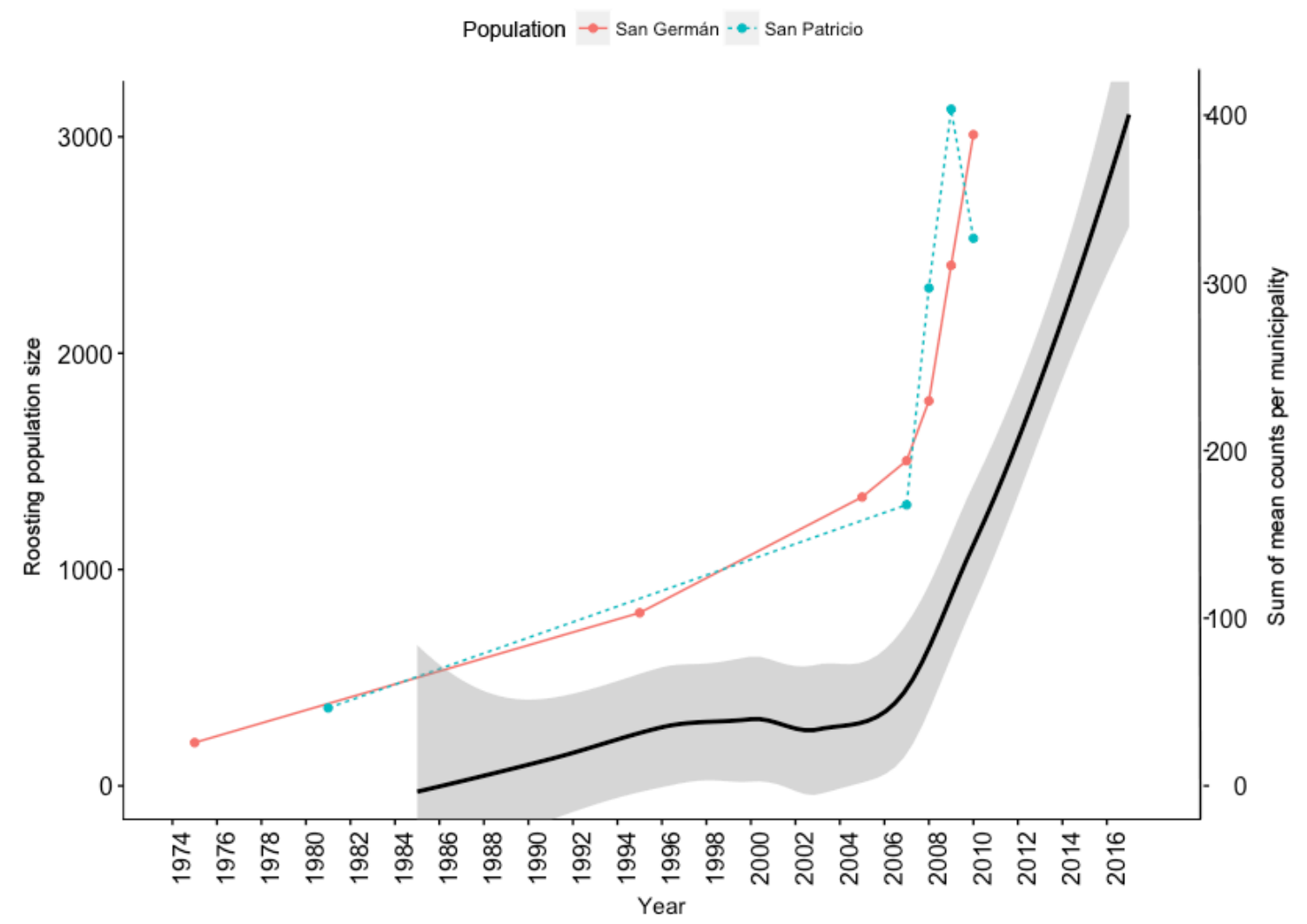

Figure 3: Island-wide population increase of the white-winged parakeet (Brotogeris versicolurus) in Puerto Rico (black line) and population increase in two populations (roosting sites) over the years. Island-wide population increase was calculated as the sum of the mean number of birds counted per year/municipality (data from Ebird). Grey shading indicates the $95 \%$ CI based on the local weighted scatterplot smoothing (loess). 


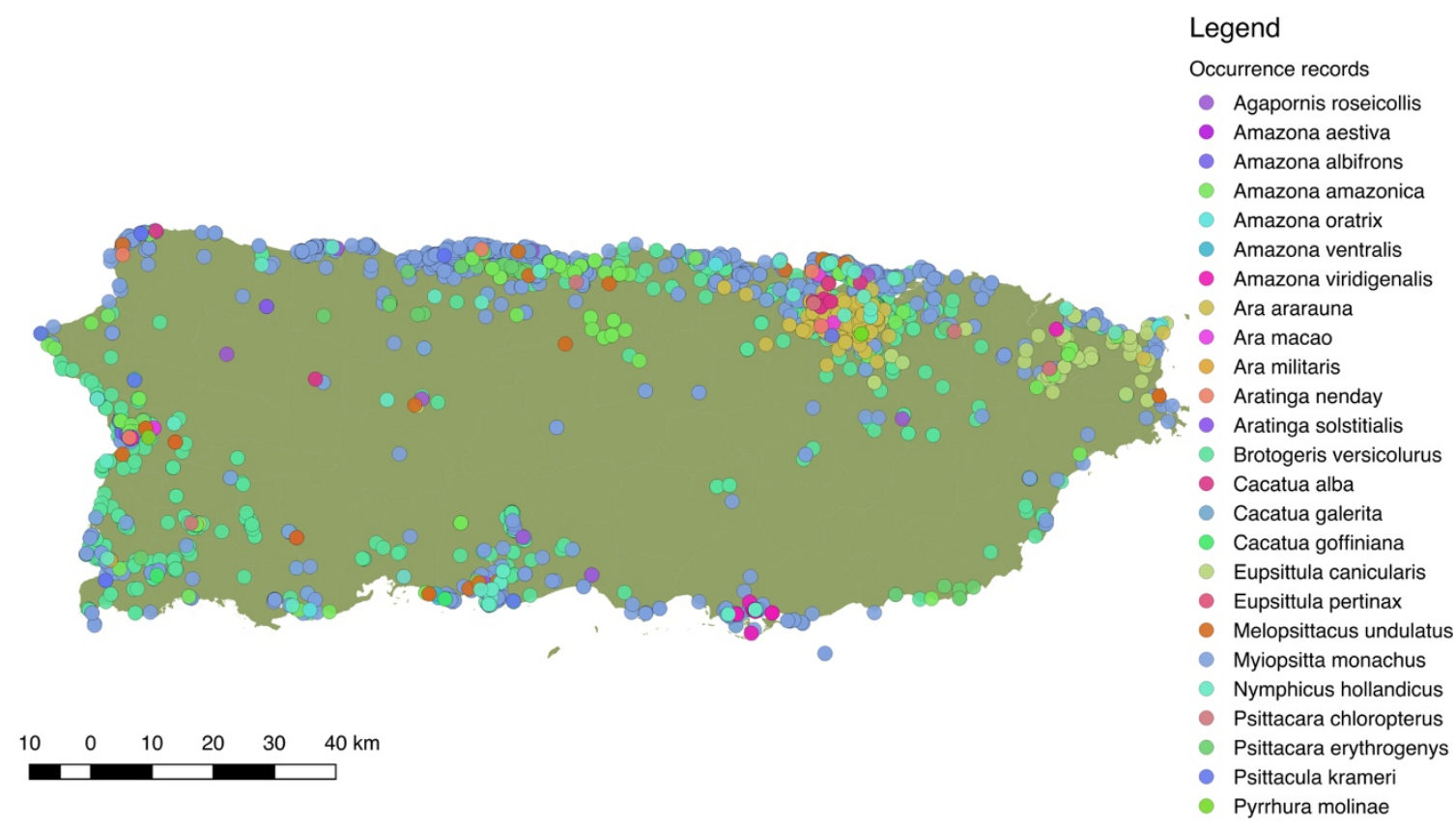

Figure 4: Distribution of 25 species of Psittaciformes in Puerto Rico, depicted by the different colors. Records originated from observations made by the authors, online databases, and reports from local birding groups (see methods). 
White-winged parakeet

(Brotogeris versicolurus)

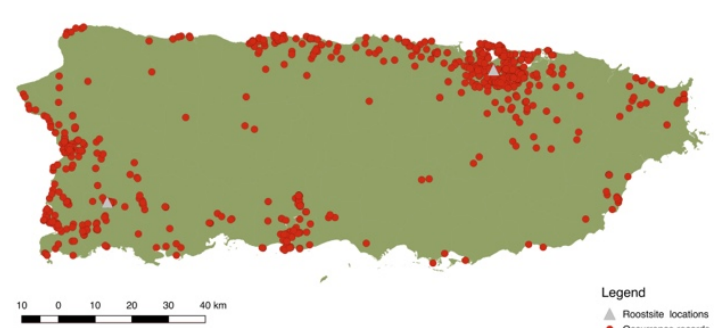

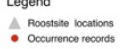

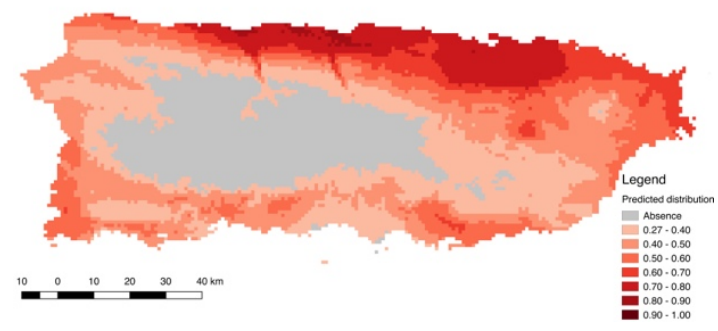

Red-masked conure (Psittacara (Aratinga) erythrogenys)
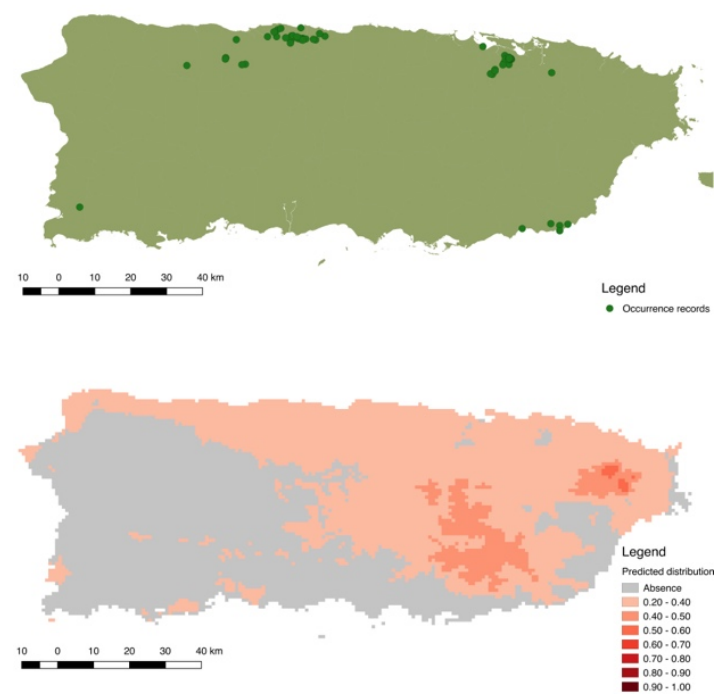

Monk parakeet (Myopsitta monachus)

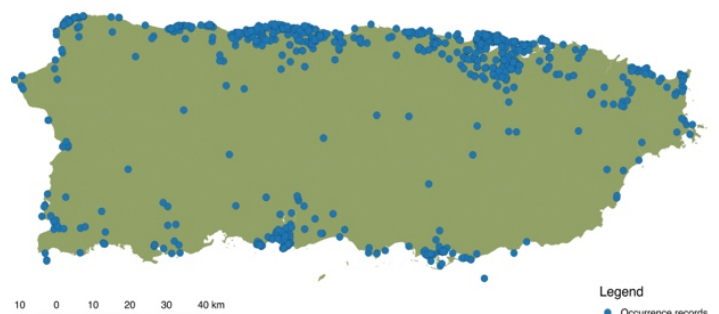

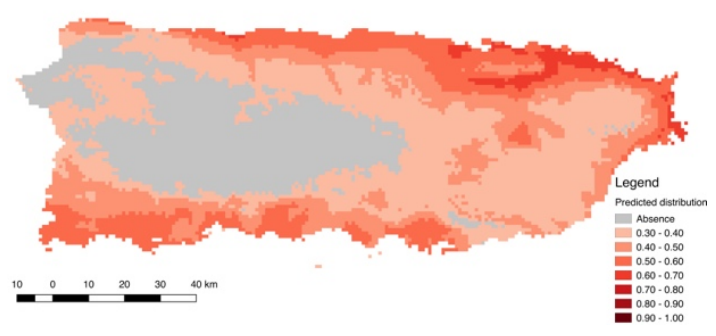

Orange fronted parakeet (Eupsittula (Aratinga) canicularis)
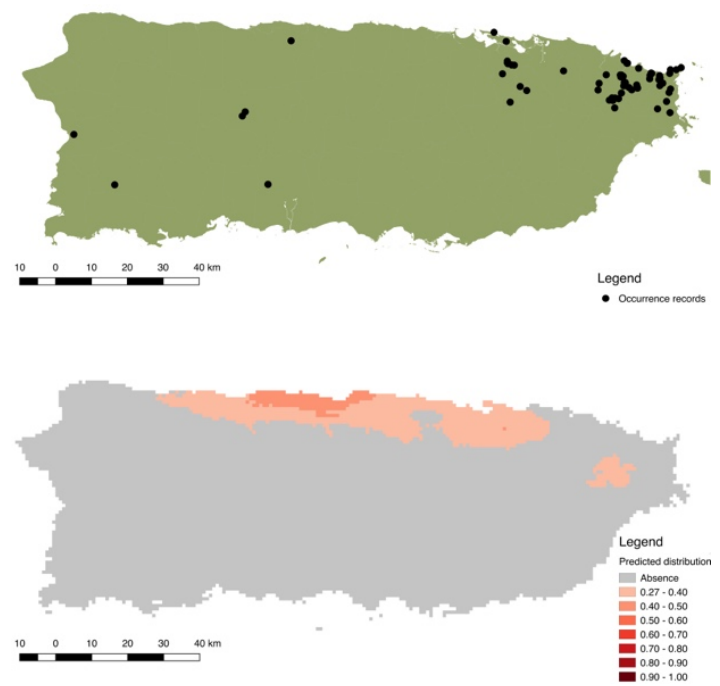

Figure 5: Current distribution of Psittaciformes in Puerto Rico whose populations are increasing (based on sighting trends, top figures with points) and the predicted distribution of the species based on the maximum entropy model (MaxEnt, bottom figures with continuous color). Warmer colors depict higher suitability. 